\title{
Temperate forest trees and stands under severe drought: a review of ecophysiological responses, adaptation processes and long-term consequences
}

\author{
Nathalie BRÉDA $^{\text {a* }}$, Roland HUC ${ }^{\mathrm{b}}$, André GRANIER $^{\mathrm{a}}$, Erwin DREYER $^{\mathrm{a}}$ \\ ${ }^{a}$ UMR INRA UHP Forest Ecology and Ecophysiology, INRA, 54280 Champenoux, France \\ ${ }^{\mathrm{b}}$ Mediterranean Forest Research Unit, INRA, 84000 Avignon, France
}

(Received 24 October 2005; accepted 28 April 2006)

\begin{abstract}
The extreme drought event that occurred in Western Europe during 2003 highlighted the need to understand the key processes that may allow trees and stands to overcome such severe water shortages. We therefore reviewed the current knowledge available about such processes. First, impact of drought on exchanges at soil-root and canopy-atmosphere interfaces are presented and illustrated with examples from water and $\mathrm{CO}_{2}$ flux measurements The decline in transpiration and water uptake and in net carbon assimilation due to stomatal closure has been quantified and modelled. The resulting models were used to compute water balance at stand level basing on the 2003 climate in nine European forest sites from the CARBOEUROPE network. Estimates of soil water deficit were produced and provided a quantitative index of soil water shortage and therefore of the intensity of drought stress experienced by trees during summer 2003. In a second section, we review the irreversible damage that could be imposed on water transfer within trees and particularly within xylem. A special attention was paid to the inter-specific variability of these properties among a wide range of tree species. The inter-specific diversity of hydraulic and stomatal responses to soil water deficit is also discussed as it might reflect a large diversity in traits potentially related to drought tolerance. Finally, tree decline and mortality due to recurrent or extreme drought events are discussed on the basis of a literature review and recent decline studies. The potential involvement of hydraulic dysfunctions or of deficits in carbon storage as causes for the observed long term (several years) decline of tree growth and development and for the onset of tree dieback is discussed. As an example, the starch content in stem tissues recorded at the end of the 2003's summer was used to predict crown conditions of oak trees during the following spring: low starch contents were correlated with large twig and branch decline in the crown of trees.
\end{abstract}

drought / water balance / time lag effect / hydraulic properties / dieback

Résumé - Arbres et peuplements forestiers tempérés soumis à sécheresse : une revue des réponses écophysiologiques, des processus d'adaptation et des conséquences à long terme. La sécheresse exceptionnelle de 2003 a été l'occasion de faire le point de nos connaissances sur les mécanismes écophysiologiques permettant aux arbres de traverser un tel évènement climatique extrême. L'analyse a été conduite à l'échelle de l'arbre et du peuplement, tandis que l'intensité de la sécheresse a été quantifiée à l'aide d'un calcul de bilan hydrique sur neuf sites forestiers européens contrastés du réseau CARBOEUROPE. Le rôle du couvert dans les échanges avec l'atmosphère est rappelé puis intégré dans l'analyse des réductions de bilan d'eau et de carbone en 2003 dus à la régulation stomatique. Les caractéristiques du complexe sol-racine, important à la fois pour l'accès à la ressource et à l'efficience de son absorption, constituent un des premiers traits d'adaptation à la sécheresse. La réponse et les adaptations des espèces ont surtout été analysées en termes de diversité inter-spécifique de fonctionnement hydraulique et du couplage entre propriétés hydrauliques et régulation stomatique. Enfin, nous discutons l'hypothèse selon la quelle les dysfonctionnements hydrauliques ou les déficits de mise en réserve sont impliqués dans les réactions différées de croissance, de développement, d'induction de dépérissement. Par exemple, des mesures de réserves glucidiques dans les troncs de chênes menées en fin d'été 2003 ont permis de prédire l'état des couronnes des arbres au printemps 2004. Les faibles taux d'amidon étaient associés à une forte mortalité de branches et de jeunes pousses.

sécheresse / bilan hydrique / effet différé / propriétés hydrauliques / dépérissement

\section{INTRODUCTION}

Productivity of forest ecosystems is severely constrained by water availability and drought may induce large-scale tree decline episodes in temperate forests. Soil water shortage impacts several steps of water transfer along the soil-treeatmosphere continuum. Drought results in the reduction in soil water availability. Drought stress occurs whenever soil water drops below a threshold inducing restrictions to growth and

\footnotetext{
*Corresponding author: breda@ nancy.inra.fr
}

transpiration. Reduced water availability alters both soil-root and leaf-atmosphere interfaces and threatens the integrity of the liquid phase continuum from soil to leaves. Water and $\mathrm{CO}_{2}$ fluxes are decreased; as a consequence, tree growth is limited and individual tree survival may become problematic in case of extreme soil water depletion.

Potential evapotranspiration (i.e., mainly irradiance and vapour pressure deficit) directly controls water fluxes along the soil-tree-atmosphere continuum. Transpiration is the driving force for water transfer, and according to the tension-cohesion theory $[4,38]$ pulls water from soil to leaves. Transpiration 
directly produces and maintains a gradient of water potential throughout the plant [35] and the ratio transpiration/water potential gradient is the whole-plant hydraulic conductance. Water transfer within trees and in the soil-plant water continuum is modelled using an electrical analogy since Van den Honert [150]. High evaporating demand and low soil water content induce a decrease of water potential all along the pathway. In addition, the decrease of soil-water content results in an increase of the hydraulic resistance within the soil and at the soil-root interface. As a result of this drop, stomatal closure occurs in most tree species, limiting water fluxes at the cost of reduced $\mathrm{CO}_{2}$ assimilation. When the intensity of drought increases, steady state conditions of water transfer (mainly in the xylem tissues) may be irreversibly disrupted, due to water cohesion break-down and massive vessel embolism. This may result in premature mortality of roots or twigs, and could ultimately lead to tree death.

In ecosystems submitted to drought, resistance, avoidance or tolerance to stress is driven by either structural or physiological adjustments, or by a combination of both. The main response of shrubs to contrasted precipitation regimes in a chaparral range is to modulate accordingly leaf area index, not to adjust physiological functions [110]. In temperate forests, repeated episodes of drought cause a decrease in leaf area index on an inter-annual time pace $[12,83]$ and hence promote a decline of gross primary productivity [82]. Mediterranean and dry-tropical vegetations adapt to severe and frequent drought episodes by adjusting species composition, leaf area duration, leaf area index, root-to-shoot ratio, leaf thickness and through physiological acclimation processes. However, the primary productivity of such drought adapted ecosystems is usually very low $[54,113,116,117]$.

Global change is expected to enhance the frequency and the severity of drought events in several regions and particularly in the Northern hemisphere [71, 124, 126, 127]. The drought episode of 2003 should then be regarded not as an isolated extreme accident, but as an event that might occur at increasing frequencies in a near future.

The drought of summer 2003 was exceptionally severe in many regions of Europe [115], as much in duration as in intensity. In some areas, it was the most severe drought recorded during the last 50 years, and lasted for over 6 months. This exceptional event exhibited a wide extension over Europe, the maximum intensity being observed within a large band extending from SW France to NE Germany. Concomitantly to drought, an extreme heat wave expanded over a large part of Europe and lasted several days. Direct damage to trees by high temperatures, as well as by ozone peaks, occurred after drought was installed, and visible symptoms (discolouration, leaf rolling, leaf or needle fall) were recorded. Nevertheless, the impact of such constraints was indirect in the sense that they affected already severely drought-stressed trees. High temperatures for instance affected trees with closed stomata that were therefore unable to cool through transpiration. As a result, leaf temperatures sometimes largely exceeded air temperatures, and probably over passed lethal thresholds for leaf tissues or pigments. Despite the importance of such secondary effects, we focussed the present review on tree and stand water relations, as primary targets of water shortage.

This review aims at synthesizing the key processes enabling forest trees and stands to cope with an extreme drought constraint. Two questions will be addressed: (1) what are the factors that could contribute to stand vulnerability or resilience under extreme drought and (2) what is the degree of diversity in the responses to drought among tree species. We begin with processes involved at soil-root and canopy-atmosphere interfaces that will be illustrated with results gained from water and carbon flux measurements. Stand water balance will be computed from the actual 2003 weather in Europe in order to derive realistic estimates of the soil water deficit that occurred during this summer and to produce a quantitative index of water shortage and drought stress. In a second section, we analyse the risk of drought-induced irreversible damage to xylem water transfer, with a special attention to inter-specific diversity among a wide range of tree species. Finally, we address the question of how recurrent or extreme drought events may induce tree decline and mortality, on the basis of a literature review and of studies on recent decline episodes.

\section{WATER BALANCE AND SOIL WATER SHORTAGE}

Water flow in the soil-plant continuum results from a gradient of water potential between soil-root interface and leaves. Leaf water potential decreases as evaporative demand (potential evapotranspiration) increases and also as soil dries. As long as soil water supply is sufficient to compensate for evapotranspiration, water flow along the soil-tree-atmosphere continuum is conservative and no down-regulation occurs. The two key interfaces are then the soil-to-root interface, where trees take-up water and the leaf-atmosphere interface, where the main control of transpiration occurs.

\subsection{Soil-root interface and water absorption}

The efficiency of any tree in terms of water relations depends on its ability to absorb water at a rate able to prevent internal water deficits during periods of high transpiration. Water supply to trees implies two major steps: absorption and transport of water (i.e. ascent of sap), both driven by transpiration. The efficiency of soil water absorbtion in trees depends on both spatial extension and density of their root system [87].

Spatial extension: Water uptake by individual trees depends on fine root exchange surface, i.e., on their cumulated length or biomass. The presence of a deep, ramified and dense root system is one of the most effective traits conferring drought tolerance as it provides trees with access to larger soil water reserves. Trees that develop intensively branched and deeply penetrating root systems are able to mobilize a larger fraction of available soil water and nutrients. Both vertical root distribution and seasonal root growth dynamics are closely depending on physical soil properties (mainly texture like clay 


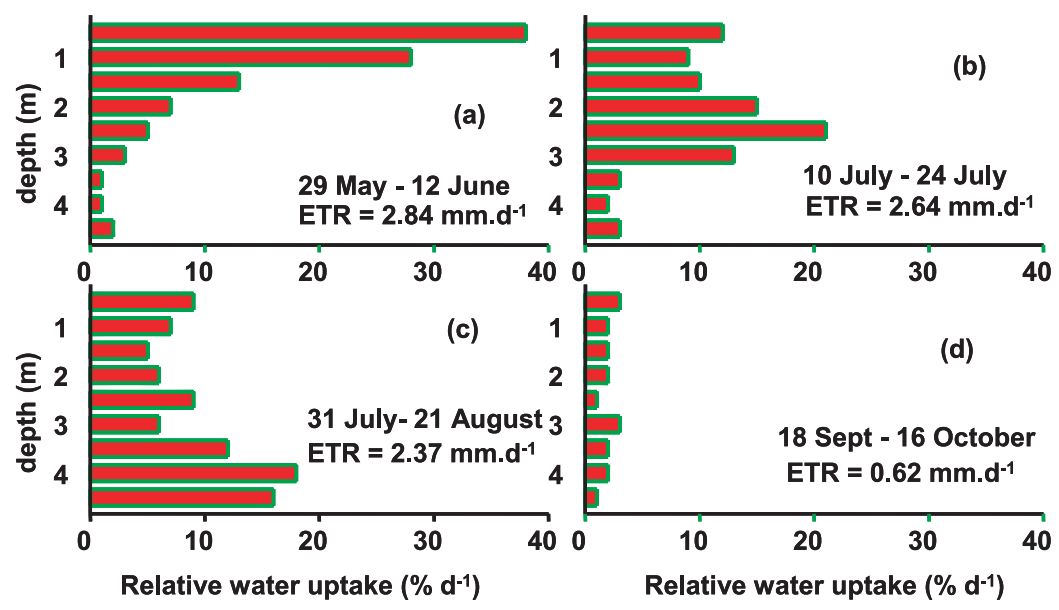

Figure 1. Contribution of different soil layers to the overall water uptake (ETR) by a Quercus coccifera L. evergreen scrub at different dates during drought progression. From Rambal S. [114].

content, bulk density, content of coarse elements...) and physiological constraints for root survival and development (water table, oxygen supply, nutrients, aluminium or manganese toxicity, soil pH). But climate itself could influence fine root dynamics [44]: data from a literature survey support the view that rainfall is one of the major environmental factors controlling fine root biomass in Fagus sylvatica [86]. Surprisingly, an exceptionally small fine root biomass was detected in a dry beech stand as compared to five other stands with higher rainfall [86]; this could be due to a large mortality of fine roots during peak drought. It is also well established under continental $[19,50]$ or Mediterranean climates ([114], Fig. 1) that soil water uptake displays a gradual downward shift as the soil dries out, and that a small fraction of total fine roots, growing deeper into the soil, ensures the overnight recovery of the soil to tree water potential equilibrium $[8,19]$, and supports a fraction of tree transpiration during periods of stomatal closure. At least this small fraction of root systems enables survival of the trees by providing the unbearable amount of water.

Uptake efficiency: Fine root tips, closely associated in forests with mycorrhizae, are the most important fraction of the root system for water and mineral uptake [34]. Ectomycorrhizal symbioses may improve water status of saplings [49] and probably also trees under drought, by means of increased absorbing surface, of efficient conduction through mycelial strands, of enhanced hydraulic conductivity at the soil-root interface or of hormonal and nutritional effects modifying stomatal regulation of the tree $[18,61,62]$. Development of mycorrhizal roots considerably increases the exchange surface of the root system. The rate and periodicity of root growth is less well known under field conditions. Most of the studies reported the occurrence of two periods of active root growth, namely during spring and early autumn. The two periods of slowest root growth occur during winter and summer, and coincide with lowest soil temperatures and with lowest soil moisture, respectively. Recent surveys in beech stands demonstrated a larger sensitivity (estimated from decreased respiration) of Lactarius sp. to declining soil water potential as compared to
Cenococum geophilum [73]. Cenococcum is likely more able to maintain the physiological integrity of beech roots facing drought than Lactarius. This fungus infected free root apices and expanded while the other ectomycorrhizas declined due to soil water shortage. Moreover, the overall large diversity of ectomycorrhizal communities evolves with season, and responds strongly to soil moisture. As a result, metabolic activities in the rhizosphere depend on soil water availability [23]. Both qualitative (shift in fungal community) and quantitative changes in ectomycorrhizal colonization have been recently reported in pine stands among sites affected by high or low mortality following an extreme drought event [141]. Another example of the importance of roots is the fact that pine trees established while silver fir and spruce failed, and that this resulted from pines displaying 24 times as many root branches and tips and 8 times the absorbing surface than the two other species (Nobbe cited by [80]).

The efficient zone of water absorption is usually close to root tips. Water absorption is affected by several factors, including plant-dependent [85] and environmental factors. Water absorption takes place whenever a decreasing gradient of water potential occurs from soil to roots, this gradient being largely controlled by tree transpiration and soil water content. Soil water potential depends on soil water availability, and is largely depending on the surface forces which bind water to the soil particles (matrix potential) and is hence modulated by soil texture (silt, loam, silty clay...). Finally, water absorption is enhanced by warmer soil temperature, due to increased hydraulic conductivity in the roots and decreased kinematic viscosity of water, while soil aeration prevents roots from $\mathrm{O}_{2}$ deficiency and resulting decay [80].

The maximal depth of water uptake by trees is one of most important functional information for drought avoidance and for water balance calculation, but it is also one of the most difficult to record. Direct observations of the vertical distribution of fine roots are painful and require deep trenches and careful observations. New perspectives for analysing water absorption by tree root systems in situ are under study, using 
miniature sap-flow gauges mounted on small-diameter roots coupled to an analysis of the spatial heterogeneity of root water uptake [34]. The more recent progress in our understanding of water absorption comes from indirect assessments, using stable isotopes of oxygen and hydrogen (deuterium) or in situ water absorption by fine roots. The measurement of deuterium isotope ratios helps to determine the relative uptake of groundwater vs. growing season rainfalls [154], provided the two water sources display different isotopic signatures, which is usually but not always the case. Other possible water sources, like deep water, can also be identified using deuterium labelling as recently demonstrated in a Mediterranean stand of Pinus nigra [108]. The isotopic signature of water uptake is also very efficient to analyse mixed stands with contrasting root systems exploiting different water sources from contrasting soil compartments or directly from the water table $[16,22,42,99]$. Unfortunately, the technical limitations of isotopic tools are numerous, particularly for applying it within forest stands. Natural isotopic abundance is not always differing enough along the soil profile; so that the isotopic composition of xylem sap provides no clue to the depth of water uptake. Experimental tracing using isotope injection into the soil profile by controlled irrigation has been seldom used in forests, due to the high level of tree water consumption and to the depth to be labelled. Another indirect approach is the use of numerical simulation models basing on parameters derived from intensive measurements of seasonal patterns of soil water content and of tree transpiration and leaf water potentials, and of climatic data [19]. The gradual increase in the resistance to water flow from soil to roots due to soil water depletion can then be simulated [11]. We demonstrated that the reduction of soil-to-leaf hydraulic conductance under drought is in first instance due to the increase of soil-to-root resistance. This resistance becomes limiting as soon as soil volumetric water content drops below 0.33 in loamy soils, i.e., as soon as the macro-pores in the soil are water-depleted. Such levels of soil water depletion are frequently encountered during summer. Both modelling and direct field measurements confirmed that water uptake from the wetter layers of the rooting zone were able to partly compensate for the water deficit in drier top layers containing only fine roots and helped trees to survive, despite the low root density encountered in such deep soil layers $[24,72,134]$.

\subsection{Canopy-atmosphere interface}

Canopy development, which can be quantified by leaf area index (LAI), is well known to directly control both transpiration and rainfall interception.

Rainfall interception, i.e., the free water that evaporates directly from leaves and bark after rains, represents a loss for the forest floor as this water never reaches the soil surface [6]. However, during evaporation of the intercepted water, tree transpiration is reduced or sometimes even stopped; the net water loss by the stand can therefore be slightly lowered with respect to dry canopies. As proposed by Rutter [123], tree transpiration is reduced by about only $20 \%$ of the equiva-

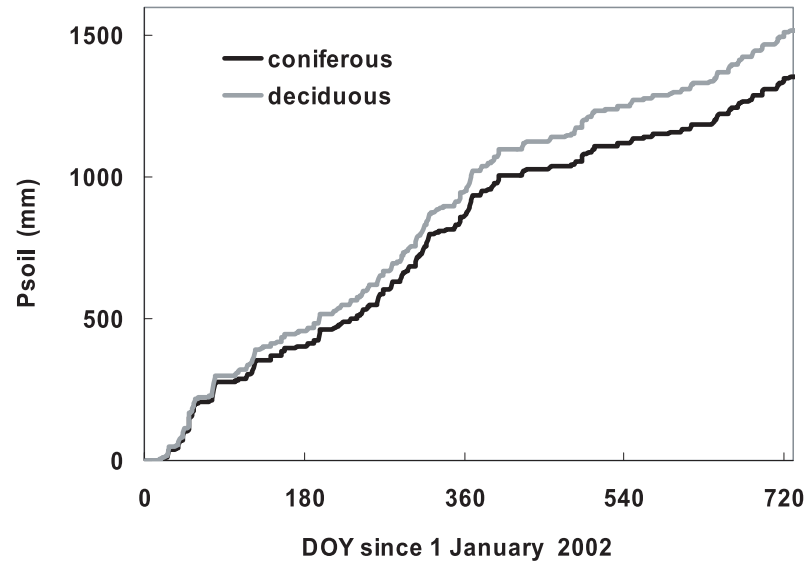

Figure 2. Simulation of cumulated throughfall $\left(P_{\text {soil }}\right)$ below coniferous (spruce) and deciduous (beech) stands displaying each a leaf area index of 7.5. The simulation bases on real daily rainfall data from years 2002 (wet) and 2003 (dry) and starts on January 1, 2002. Simulation with the daily water balance model BILJOU [55].

lent intercepted water [7]. Therefore, the net water loss resulting from interception is about $80 \%$ of the intercepted water. The development of mechanistic models [52] allows accurate estimates of the net interception when climatic variables are available at the hourly time-step and when canopy properties, as the vertical distribution of leaf surfaces and aerodynamic resistances, are known [52, 53, 89, 90].

Rainfall interception varies to a large extent, due to:

- Climate, especially rain distribution and irradiance, wind speed and vapour pressure deficit [7]. Higher interception rates are found under conditions of frequent and shallow rainfall, and under high potential evapotranspiration.

- Tree species, higher interception rates being generally recorded in coniferous stands [7].

- Leaf area index, upon which the water storage capacity of canopies depends directly $[10,55]$.

Under temperate and continental climates, rainfall interception typically ranges between 20 and $35 \%$ of cumulated rainfall during the leafy phase. Due to their permanent foliage, the annual cumulated interception of evergreen forests (Mediterranean species, conifers) is larger than in deciduous species. As a consequence, evergreen forests are more frequently submitted to soil water shortage under similar rainfall than deciduous stands (see Fig. 2). This is probably one of the most important causes of variation in the net availability of rain water among forest stands.

Transpiration $(E)$ is driven by the evaporative demand involving vapour pressure deficit, radiation, air temperature and wind speed. Transpiration can be modelled by the PenmanMonteith equation using a big-leaf approach, in which the canopy conductance for water vapour $\left(g_{\mathrm{c}}\right)$ plays a major role. In tightly coupled forest canopies, the following simplified formula of Mac Naughton and Black [98] provides a proxy of stand transpiration:

$$
E=\rho C_{\mathrm{p}} v p d g_{\mathrm{c}} / \lambda \gamma
$$



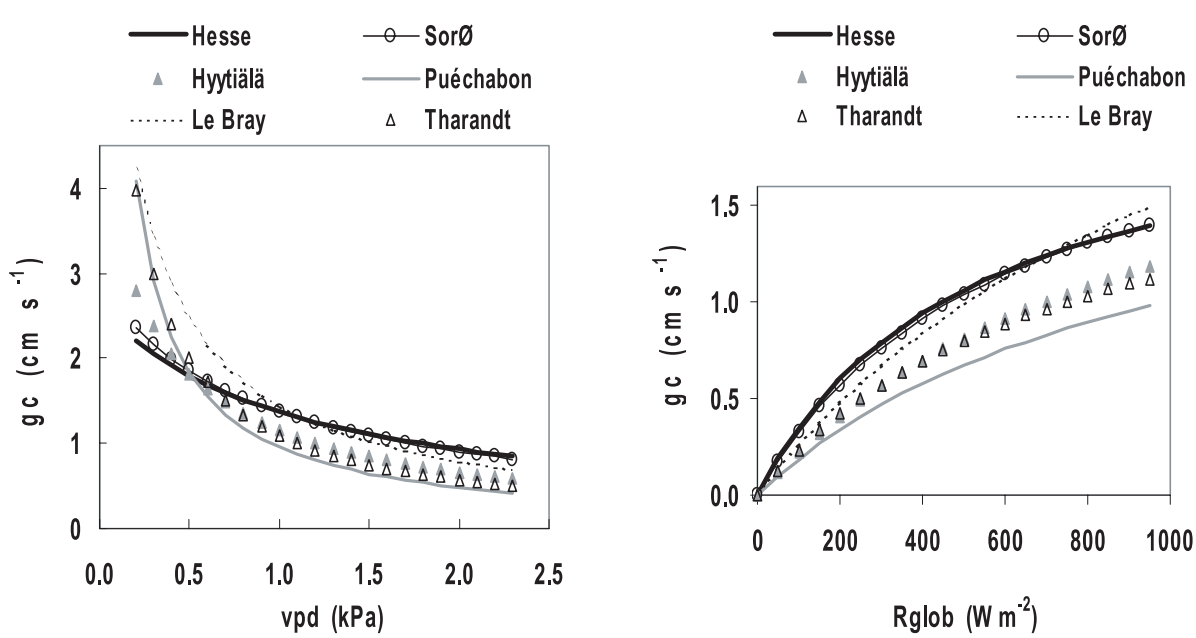

Figure 3. Canopy conductance $\left(g_{\mathrm{c}}\right)$ as a function of vapour pressure deficit ( $v p d$, left) and of global irradiance $\left(R_{\mathrm{glob}}\right.$, right) in six European forests: Hesse and Sorø (beech), Hyytiälä (Scots pine), Puéchabon (evergreen holm oak), Le Bray (maritime pine), Tharandt (spruce). Carbodata research program, unpublished data.
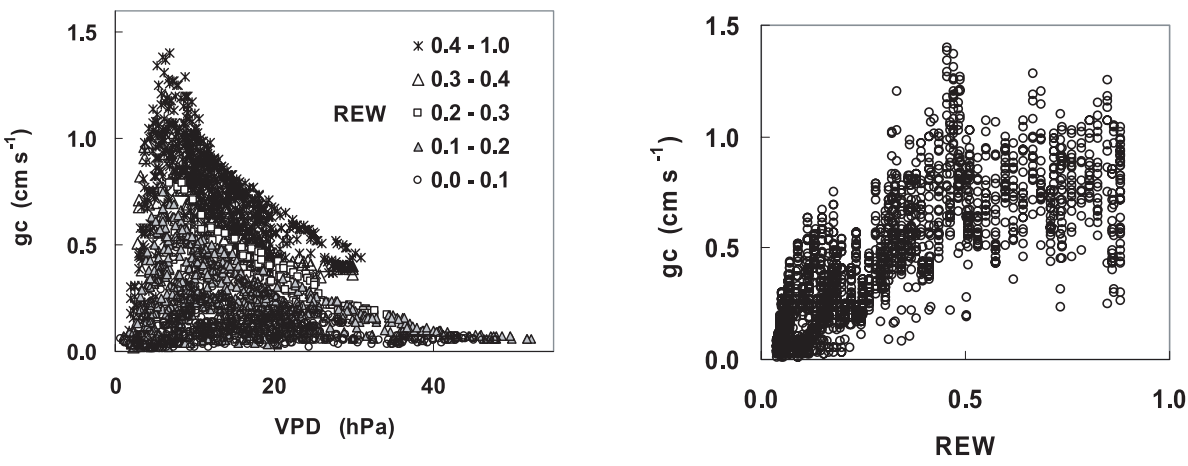

Figure 4. Left: effect of vapour pressure deficit $(v p d)$ and of relative extractable soil water $(R E W)$ on canopy conductance $\left(g_{\mathrm{c}}\right)$. Right: canopy conductance as a function of $R E W$. Canopy conductance was calculated half-hourly from stand-scaled sap flow measurements, under high irradiance $\left(>250 \mathrm{Wm}^{-2}\right)$. Data from the beech forest of Hesse (NE France).

in which $\rho$ is the air density, $C_{\mathrm{p}}$ is the heat capacity of air, vpd is the vapour pressure deficit, $\lambda$ is the specific latent heat of vaporization of water, and $\gamma$ is the psychrometric constant. Canopy conductance can be calculated by inverting the Penman-Monteith equation, from either stand-scaled sapflow [57] or from vapour flux measurements above the stand [56]. Under large soil water availability, $g_{\mathrm{c}}$ varies with both irradiance and vpd: similarly to stomatal conductance: $g_{\mathrm{c}}$ increases when incident irradiance increases, and sharply decreases when vapour pressure deficit increases. The effect of high temperatures is much less documented because they scarcely occur in temperate and continental condition and they interact with drought; in 2003 , high temperatures $\left(>40{ }^{\circ} \mathrm{C}\right)$ were reached when soil water reserves were almost completely depleted.

The European forest canopies, whether deciduous, coniferous or Mediterranean, display similar variations of $g_{\mathrm{c}}$ with irradiance with no saturation under highest irradiance (Fig. 3). However, differences can be observed in: (i) the responses of $g_{\mathrm{c}}$ to $v p d$, beech stands appearing slightly less sensitive, (ii) maximum $g_{\mathrm{c}}$, which is mainly dependent on stand leaf area index. Like for stomatal conductance at leaf scale, increasing drought induces a decrease in $g_{\mathrm{c}}$.

Drought intensity is best quantified in the form of relative extractable soil water $(R E W)$. $R E W$ may be computed at any given time, from soil water content in the root zone as follows:

$$
R E W=E W / E W_{0}
$$

where $E W$ is the actual extractable soil water. $E W_{0}$ is defined as the difference in soil water content between field capacity and the minimum water content (usually taken as the permanent wilting point) in the whole rooting zone. $R E W$ varies between 1 (field capacity) and 0 (permanent wilting point).

When $R E W$ varies between 1.0 and $0.4, g_{\mathrm{c}}$ remains high and depends only on air humidity and irradiance. During water shortage, when $R E W$ drops below ca. $0.4, g_{\mathrm{c}}$ declines gradually down to very low values (Fig. 4). During a dry period nevertheless, even shallow rainfall events induce higher than expected values of $g_{\mathrm{c}}$, because stomata re-open when free water reaches the superficial fine roots during the 2-3 days after rainfall. Under severe water stress $(R E W<0.1), g_{\mathrm{c}}$ displays a very 


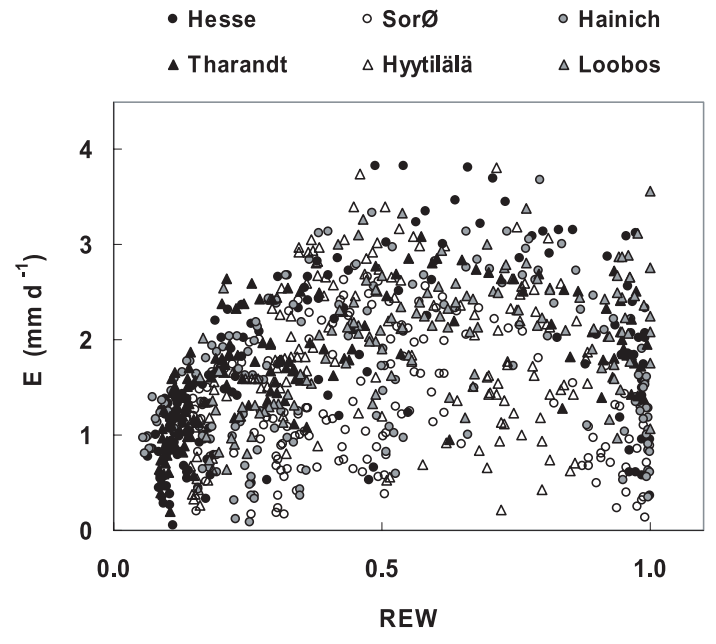

Figure 5. Evapotranspiration fluxes ( $E$, daily values) measured with an eddy-covariance method, as a function of relative extractable soil water $(R E W)$ in six European forest stands of the Carboeurope network (from Granier et al. [58]). Hesse (France), Hainich (Germany) and Sor $\varnothing$ (Denmark) are beech stands, Tharandt (Germany) is a spruce stand, Hyytiälä (Finland) and Loobos (The Netherlands) are Scots pine stands.

lower sensitivity to vpd, probably because stomata are fully closed and residual transpiration is mostly cuticular (Fig. 4). Stand transpiration is reduced in parallel to $g_{\mathrm{c}}$ below the same $R E W$ threshold of 0.4 , as shown by eddy-covariance measurements of above canopy water vapour fluxes during 2003 in six forest stands (Fig. 5).

\subsection{Water balance and water shortage}

The daily water balance model BILJOU [55] allows a computation of water fluxes (tree transpiration, understorey evapotranspiration, rainfall interception, drainage) and of soil water content in the root zone. Tree transpiration is calculated from the Penman-Monteith equation [102]. Stomatal regulation during water stress and changes in leaf area index are modelled according to Granier et al. [55, 56]. Site-related parameters of the model include: (1) stand structure and tree phenology: maximum LAI, and for deciduous forests the dates of budburst and of complete leaf fall, and (2) soil properties described with a multilayer sub-model (for each soil layer: maximum extractable water, vertical distribution of fine roots, bulk density, water content at $-1.6 \mathrm{MPa}$ and porosity according to water content).

Three variables are calculated to quantify the intensity of drought experienced by the stand: start of the period of water deficit (i.e., day of year when $R E W$ drops below 0.4), duration of the deficit (i.e. number of days with $R E W<0.4$ ) and intensity (i.e. $\Sigma[(0.4-R E W) / 0.4]$ cumulated over the number of days with $R E W<0.4$ ), which is dimensionless and ranges between 0 (no drought) and ca. 90-100 for the highest drought intensities. Calculations of both deficit duration and intensity were performed over the vegetation period: from budburst to
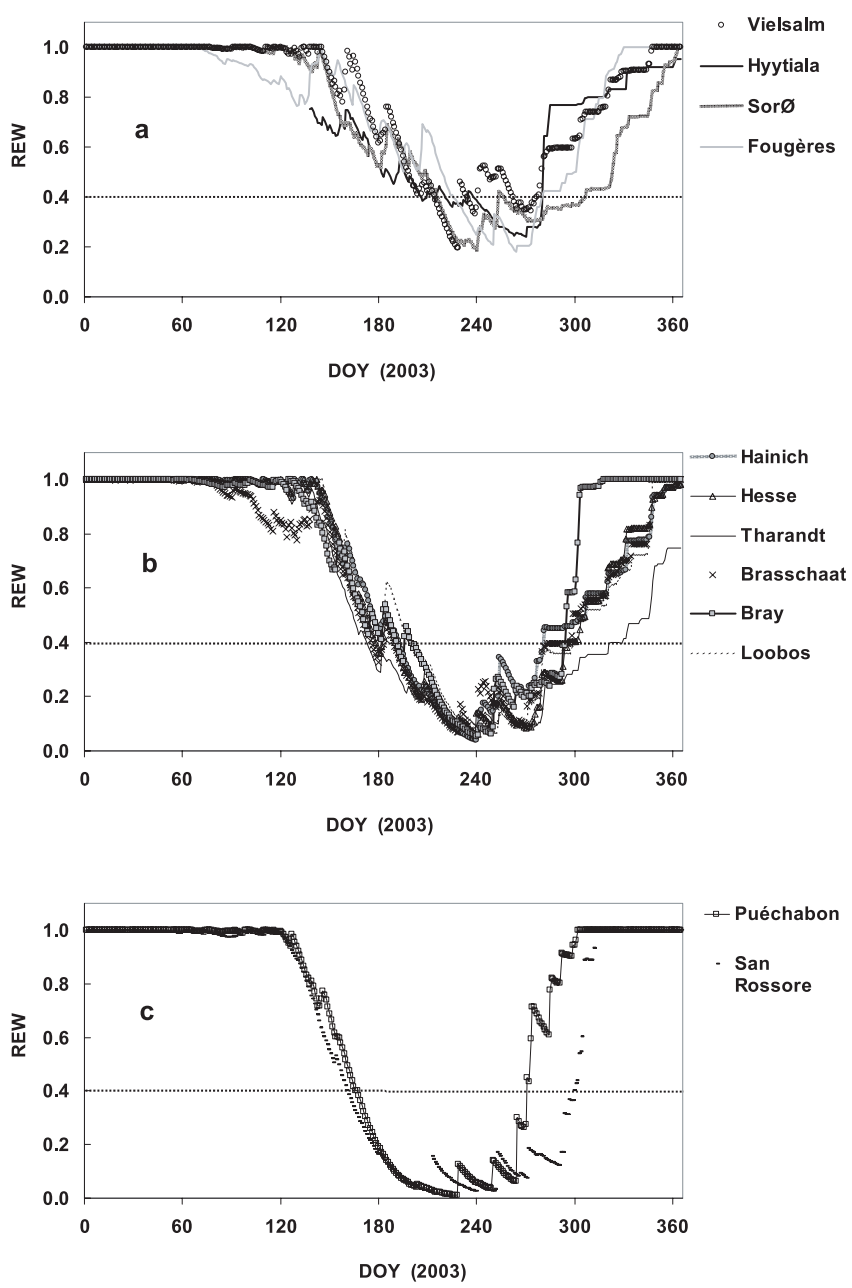

Figure 6. Seasonal time course of simulated relative extractable soil water $(R E W)$ in 12 forest stands during the year 2003. Figures a to $\mathrm{c}$ display stands ranked according to the intensity of drought reached during August 2003: (a) low to moderate, (b) severe, (c) very severe. From Granier et al. [58].

leaf fall in deciduous stands, or over the whole year in coniferous and Mediterranean stands. This model was run with data from 12 European forest sites from the Carboeurope network using above-canopy measurements of climate (rainfall, global radiation, air temperature and humidity, wind speed).

The resulting time-course of $R E W$ is presented in Figure 6 for year 2003. Three different patterns were observed: (1) at Vielsalm, Hyytiälä, Sorø and Fougères drought remained moderate, as $R E W$ never decreased below 0.2 ; (2) at Hainich, Hesse, Tharandt, Brasschaat, Le Bray and Loobos, drought was severe as it lasted during more than 2 summer months and as $R E W$ dropped to ca. 0.05 ; (3) at the two most southern sites, Puéchabon and San Rossore, drought was the most severe, $R E W$ dropping to 0 during mid-August.

Such water balance simulations allowed mapping the distribution of drought intensity over Europe. The area of most severe drought intensity extends over a large band oriented from South-West to North-East. The north-western coast of 
France, the North Sea and the Baltic Sea area were less affected [58]. This distribution over a large fraction of Europe is also reported by global modellers [25].

\subsection{Impact of reduced soil water content on carbon assimilation and cycling}

The 2003 summer drought severely reduced $\mathrm{CO}_{2}$ uptake by forests like it did for evapotranspiration. The time-course of net ecosystem exchange (NEE) measured above the stands, is presented in Figure 7 for nine European forest stands, including deciduous, coniferous and Mediterranean species. Carbon uptake (NEE) reached a maximum between days of year (DOY) 150 and 170 (depending on site), and thereafter rapidly decreased. At peak drought intensity (around DOY 220-240), NEE turned to positive, i.e. carbon was released by the ecosystems to the atmosphere. From measured NEE, gross primary production (GPP) and total ecosystem respiration (TER) were distinguished [116]. In all investigated sites, TER was positively correlated to soil temperature according to a $Q_{10}$ function. GPP and TER also showed a tight dependency on soil water content (Fig. 8) and in all investigated sites, the two fluxes decreased in response to increasing drought. Except in Vielsalm where drought remained moderate, coefficients of correlation of the fitted relationships of GPP and TER with $R E W$ varied between 0.5 and 0.8 according to the sites. These results illustrate the tight coupling between net $\mathrm{CO}_{2}$ assimilation and ecosystem respiration (Fig. 8).

Flux measurements showed that both carbon and water fluxes were reduced during increasing drought, mainly due to stomatal closure. However, in most tree species, a more severe limitation occurred for transpiration than for NPP and water use efficiency (ratio of carbon uptake to transpiration) generally increased during drought.

\section{HYDRAULIC PROPERTIES OF TREES AND INTER-SPECIFIC DIVERSITY IN VULNERABILITY TO DROUGHT-INDUCED DAMAGES}

Transpired water moves from soil to plants and to the atmosphere along a continuum of gradually decreasing water potential $(\psi)$. Water transfer in the liquid path from soil to leaf, assuming a conservative water flux within the tree, follows the relationship:

$$
E=K_{\mathrm{L}}\left(\psi_{\text {soil }}-\psi_{\text {leaf }}\right)
$$

where $E$ is the transpiration per unit leaf area, $\mathrm{mmol} \mathrm{s}^{-1} \mathrm{~m}^{-2}$.

$K_{\mathrm{L}}$ is the leaf-specific hydraulic conductance at tree scale, mmol m${ }^{-2} \mathrm{~s}^{-1} \mathrm{MPa}^{-1}$.

$\psi_{\text {soil }}-\psi_{\text {leaf }}(\mathrm{MPa})$ is the difference between soil and leaf water potential [136]. When soil moisture declines due to drought, or when transpiration increases, leaf water potential decreases and tensions $\left(\Psi_{\mathrm{X}}\right)$ in the water capillaries in xylem tissues increase. This increase may at term induce catastrophic embolism affecting water transfer through a drastic reduction of $K_{\mathrm{L}}$.
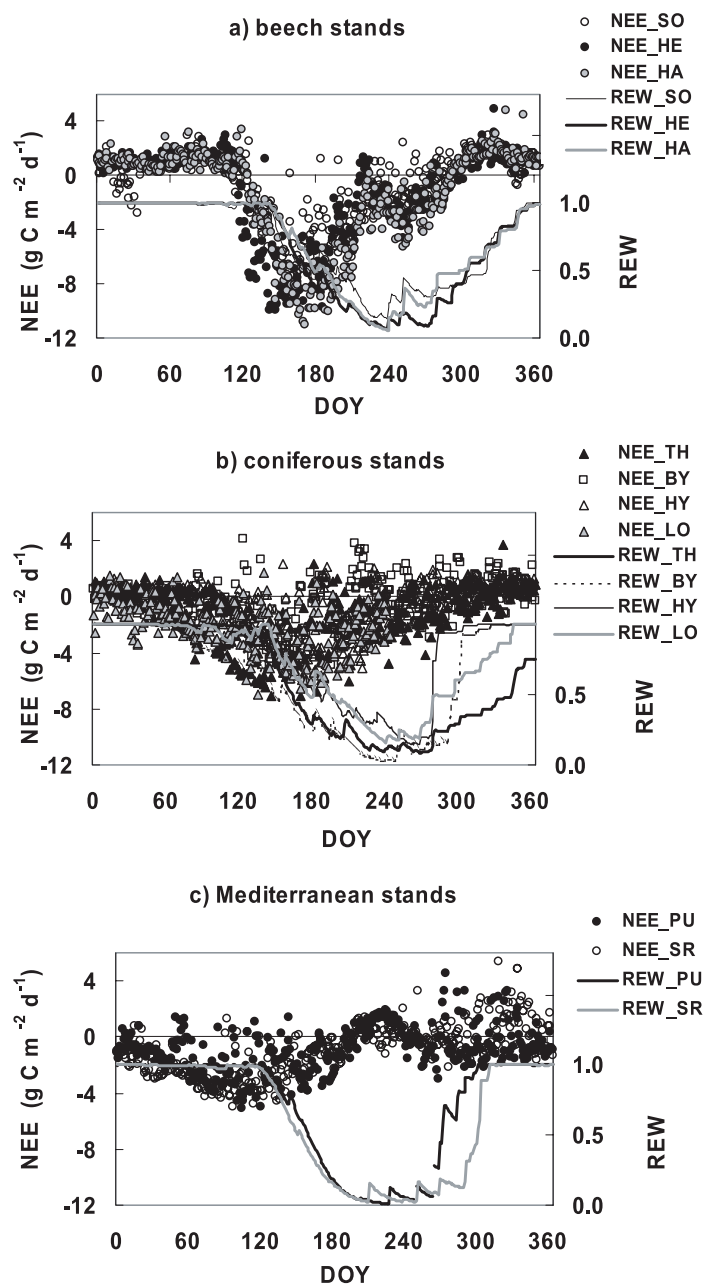

Figure 7. Time course of net ecosystem $\mathrm{CO}_{2}$ exchange (NEE, daily data) and of relative extractable soil water $(R E W)$ in: (a) beech stands (Soroe, Hesse and Hainich), (b) coniferous stands (Tharandt, Hyytiälä and Loobos), (c) Mediterranean stands (Puechabon, San Roccore). NEE $<0$ means that $\mathrm{CO}_{2}$ is taken up by the forest. When $\mathrm{NEE}>0, \mathrm{CO}_{2}$ is released. From Granier et al. [58].

Water tension reached anywhere in the xylem of trees can be mapped according to the actual water flux $F$ (depending on transpiration) and to the conductivity $k_{\mathrm{H}}$ of the organ (petiole, leaf, stem and root) [146]. At branch level, the water flux $(F)$ through a segment depends on the gradient of water potential within the segment and the hydraulic conductance per unit length, i.e., the conductivity of the segment.

This conductivity can be expressed as a function of the leaf area connected to the segment $\left(K_{\mathrm{L}}=K_{\mathrm{H}} / A_{\mathrm{L}}\right)$ and is then defined as the leaf specific conductivity [147]. It can also be expressed as a function of the transverse sapwood area of the segment $\left(K_{\mathrm{S}}=K_{\mathrm{H}} / A_{\mathrm{S}}\right) . K_{\mathrm{L}}$ produces an estimate of hydraulic "sufficiency" of a segment that is its ability to supply the leaves distal to that segment with sufficient water [149]. $K_{\mathrm{S}}$ refers to the intrinsic "efficiency" of branches and roots to conduct water. 


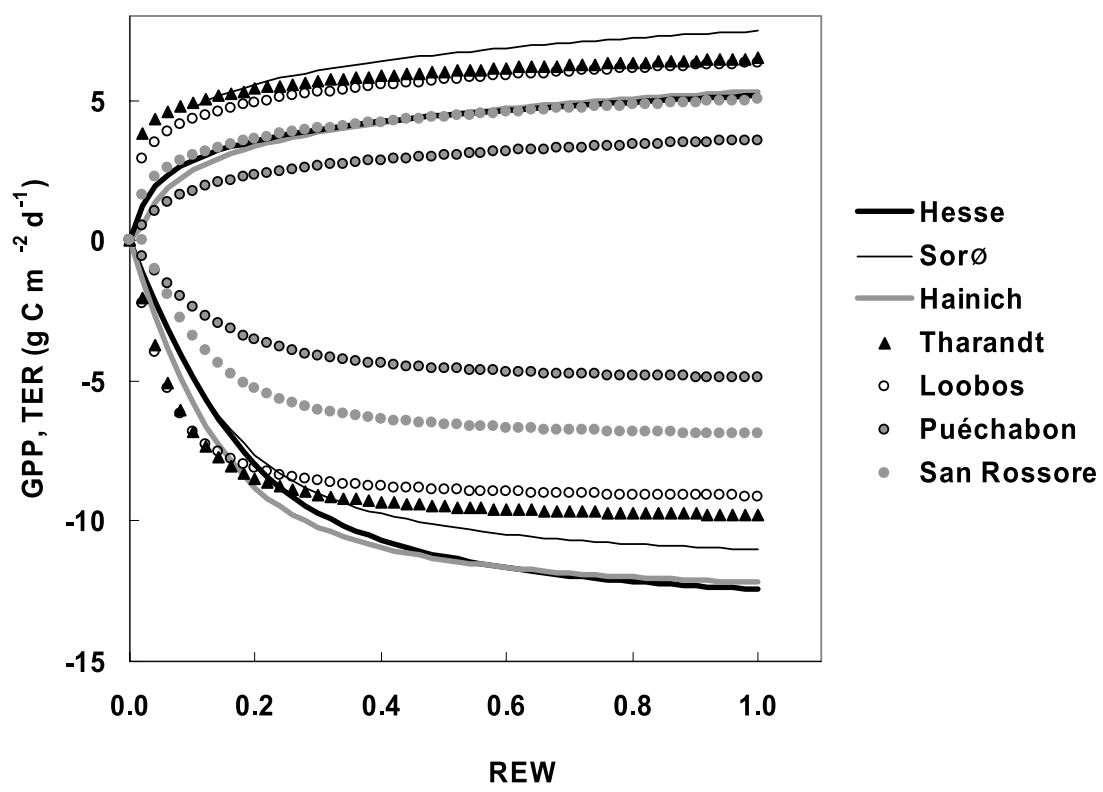

Figure 8. Effect of the relative extractable soil water, $R E W$, on gross primary production (GPP, negative) and ecosystem respiration (TER, positive). Model fitted on field data from eddy-covariance measurements in the seven forest stands listed in Figure 7.

Based on xylem anatomy [132] and plant allometry, these different properties, vulnerability to drought-induced cavitation, $K_{\mathrm{L}}$ and $K_{\mathrm{S}}$ are key parameters involved in the drought response of trees. If we consider that trees display no storage capacitance (which is close to reality, trees storing usually less than 1-2 days of transpiration), then transpiration can be expressed as $E=K_{\mathrm{L}}(-\mathrm{d} P / \mathrm{d} x)$. At a given transpiration rate, a large $K_{\mathrm{L}}$ may avoid the occurrence of large pressure gradients and limit the risk of cavitation.

Facing drought, trees have to maintain the integrity of their hydraulic system. This can be achieved by:

(1) Dynamic and reversible short term regulation processes like a reduction of transpiration by stomatal closure [133]. This may have a the additional advantage of postponing soil water depletion.

(2) Plastic and long term responses like:

- Developing a xylem with increased resistance to droughtinduced cavitation able to withstand lower water potential.

- Reduce transpiring leaf area with respect to absorbing and conductive elements. This strategy requires the modification of biomass allocation to roots vs. leaves, or can base on more or less massive leaf-shedding.

- Enhance the hydraulic conductance in the soil-leaf continuum; increased allocation of biomass to roots is probably the best way to reach this goal [134].

Plant hydraulic traits (including xylem properties, root depth, and root-leaf area ratio), and soil properties interact to modulate and limit hydraulic transfer from soil to leaves. These traits and their relationships can be used to predict optimized plant water use for specified soil drought $[101,134]$.

\subsection{Drought-induced cavitation and resulting loss of hydraulic conductivity}

Disruption in water columns within xylem elements occurs whenever sap tensions exceed a threshold value: the phenomenon is called cavitation. Its mechanism is probably as follows: the membrane of pits, allowing inter-vessel connections, may release slight air bubbles as soon as the tension of the liquid column overcomes the threshold allowed by membrane capillarity; as a consequence, the vessel empties in a few microseconds allowing the diffusion of ambient air into the cavitated vessel, and leading to an irreversible embolism when the xylem element is filled up with air [35, 147].

\subsubsection{Vulnerability to drought-induced cavitation}

Vulnerability to drought-induced cavitation is an intrinsic property of the conductive elements, and is frequently quantified as the xylem water potential inducing 50\% loss of hydraulic conductance $\Psi_{50}$. Within an organ, wider conduits are generally more susceptible to drought-induced cavitation, but across organs or species this trend is very weak $[64,81]$. This is probably because the cavitation threshold is generally not determined by vessel diameter but by the pore diameter in conduit walls [156]. In most plants, petioles are usually less susceptible than branches, and branches, less vulnerable than roots with exceptions like in Alnus glutinosa [63] and Populus euphratica [69]. Apical parts of trees experience the lowest leaf water potential and also the lowest vulnerability to cavitation, as reported for beech [84]: light exposed branches are less vulnerable than shade ones, submitted to lower transpiration and less negative leaf water potential [31]. A very clear hydraulic segmentation was reported for a few species 
like walnut trees (Juglans regia) [144] with petioles displaying a large vulnerability which aims at disconnecting the leaves through massive cavitation during drought and avoid irreversible damage to perennial parts of the tree. Nevertheless, this is not a general trend, some species showing more vulnerable twigs than petioles. Less data are available for roots than for branches, thus comparison between species are usually restricted to vulnerability in branches; roots were found to be less, equally or more vulnerable depending on species $[47,69]$.

Very low negative pressures $\left(\Psi_{50}\right)$ in xylem are likely to induce conduit wall collapse similar to the one detected in young pine needles [29]. A positive relationship was found between conduit wall reinforcement and cavitation resistance [65]. Greater wood density is also associated with the avoidance of wall collapse enabling drought tolerance. This last trend is more pronounced in conifers than in angiosperm.

\subsubsection{Relationships between vulnerability to cavitation and drought tolerance}

Relationships between vulnerability to cavitation and climate in the distribution area have often been investigated in tree species. Maples located in dry zones (Acer opalus, A. monspessulanum) proved less susceptible to droughtinduced cavitation than species that occurred in a wellwatered area (A. negundo, A. pseudoplatanus, A. platanoides, A. campestre) [143]. Seedlings originating from the most mesic population among four populations of Douglas-fir (Pseudotsuga menziesii (Mirb.)) were also the most susceptible to water-stress-induced cavitation [77].

Significant phylogenetically independent contrast correlations between vulnerability and annual precipitation were found in evergreen angiosperms and conifers [94]. This analysis, based on convergent evolution of vulnerability in independent taxa, supports the hypothesis that low vulnerability to embolism is a key component for drought tolerance. The authors report similar relationships using shorter terms indicators of climate like the sum of spring and summer precipitation instead of annual rainfall. However, the global data-basis used may not take into account local variations in soil water availability. A comparative ecophysiological study indicated that inter-specific variation in drought-induced xylem cavitation is often associated with differences in soil moisture availability [21].

A ranking of vulnerability to cavitation in relation to vegetation type has been proposed by Maherali et al. [94] (Fig. 9 showing higher median value of vulnerability for species from Mediterranean climate). Important differences in vulnerability were also found on a range of Mediterranean to temperate species (Fig. 10). A diverging example is Populus euphratica living in arid regions with root access to deep water table that displays higher vulnerability than $P$. alba and $P$. trichocarpa $x$ koreana from less severe bioclimatic region [69].

\subsubsection{Recovery of conductivity after drought-induced embolism}

Recovery from drought-induced embolism is rarely reported on trees when the xylem experienced low water po-

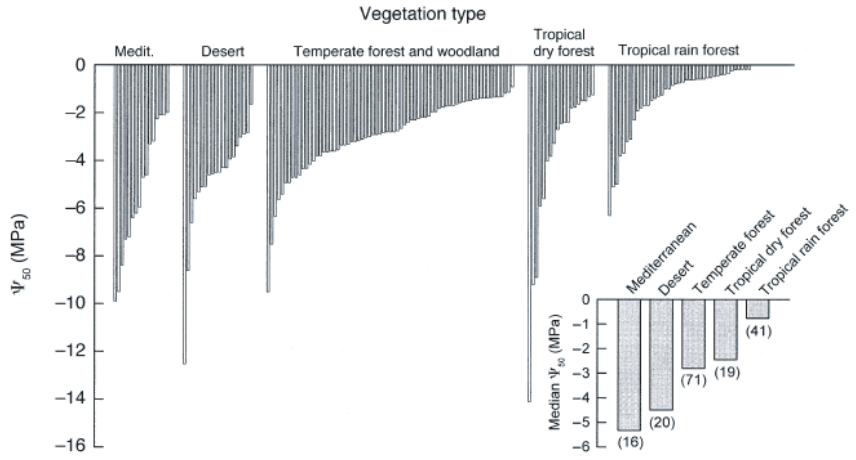

Figure 9. Distribution of vulnerabilities to drought-induced cavitation (as estimated by the xylem tension at which $50 \%$ loss of hydraulic conductivity occurs $\left[\Psi_{50}\right]$ ) in a data basis of 167 species, ranked by magnitude within five vegetation types. The median $\Psi_{50}$ for each vegetation type, along with the sample size for that group, is shown in the inset. (After Maherali et al. [94].)

tentials. More often in trees, the conductivity is restored only the following year by the formation of a new ring of functional xylem. For tree species elaborating positive xylem sap pressures in the roots during spring like Fagus sylvatica, the recovery of conductivity is partially achieved by flushing embolised vessels with pressurized sap; full recovery of the transport ability occurs usually only after the new year ring has been developed [30]. Recovery of xylem conductivity after embolism can also occur during spring due to xylem pressure following starch hydrolysis [2]. It may also happen during transpiration, as has been reported for Laurus nobilis [125], which is able to recover despite predawn leaf water potential remaining as low as $-1 \mathrm{MPa}$. Similar refilling events have been reported for a range of species $[67,68]$. Nevertheless, the reality of such refilling of embolised vessels in transpiring trees is still a matter of debate [26] and although several models have been proposed to explain it, there is a clear need for further research in this area [26]. Anyway, embolism repair, if it occurs after drought, remains a costly process (it requires metabolic energy to generate the required positive pressures) and cavitation avoidance remains probably a much more efficient way to cope with reduced soil water, and stomatal control of transpiration plays probably a major role in this respect.

\subsection{Vulnerability to cavitation and stomatal conductance: coupling liquid and vapour fluxes}

Stomatal control of leaf transpiration and loss of hydraulic conductivity in twigs have been monitored in parallel in a range of species during the course of drought (see review in [35]). A tight coordination was evidenced between stomatal closure and induction of embolism: usually, embolism begins only when stomatal conductance drops below $10 \%$ of initial values. This supports the hypothesis that a tight control of water loss protects the xylem against drought-induced embolism [76, 148]. The range of water potential between full stomatal closure and onset of cavitation corresponds to a safety 


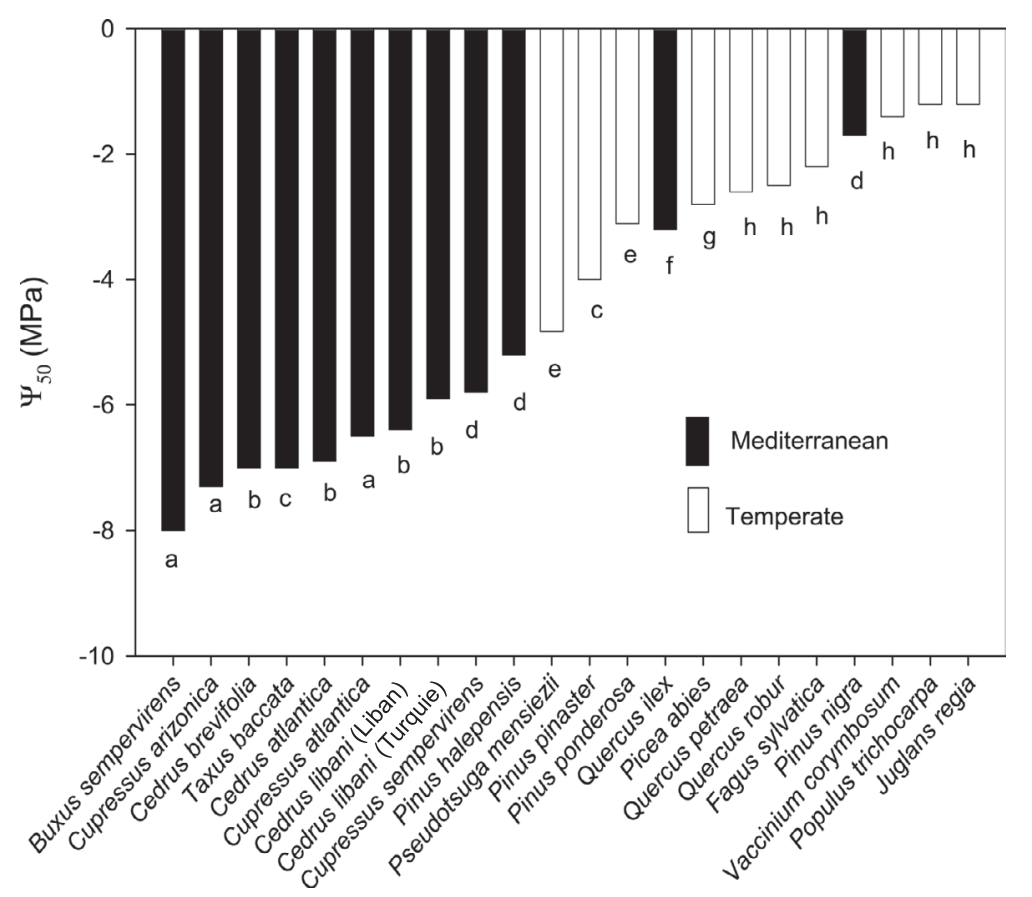

Figure 10. Vulnerability to cavitation (as estimated by the xylem tension at which $50 \%$ loss of hydraulic conductivity occurs $\left[\Psi_{50}\right]$ ) in several Mediterranean species compared to various temperate species. Data from: Huc et al., unpublished (a); [81] (b); Cochard, unpublished data (c); [47] (d); [137] (e); [51] (f); [97] (g); [35] (h).

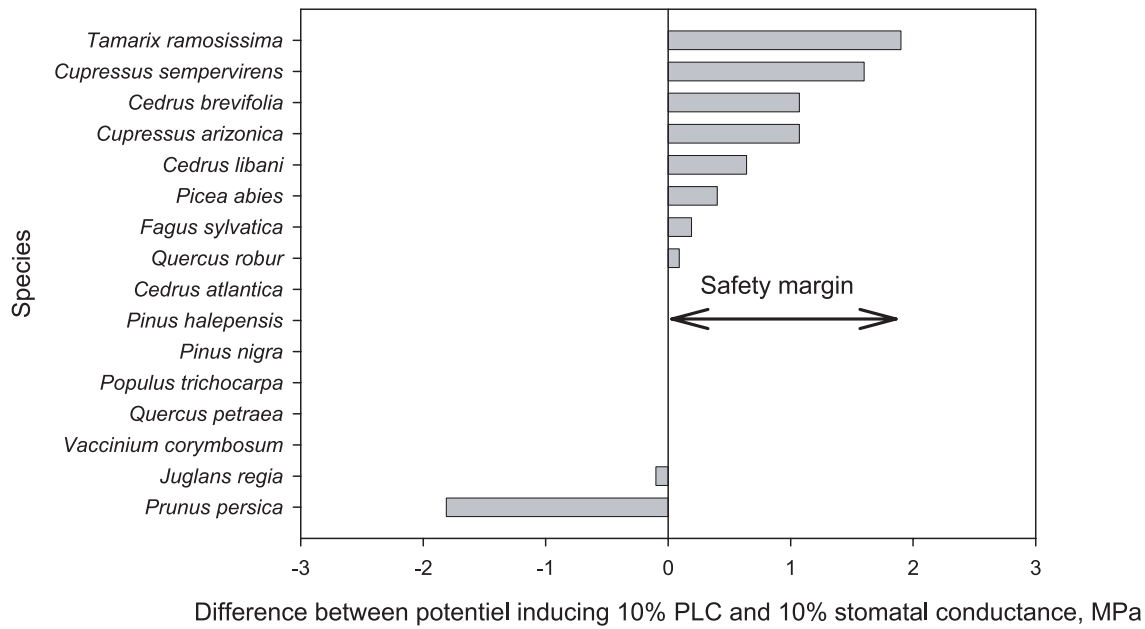

Figure 11. Margin between the water potential inducing $10 \%$ loss of conductivity in stems and the water potential inducing $10 \%$ stomatal closure for different species. Positive values correspond to a safety margin, negative ones reveal a lack of control of stomata over cavitation. Data from [109]; [47]; [81]; Huc et al., unpublished; [92]; [31]; [28]; [3]; Cochard et Ameglio, unpublished.

margin [135]. In most tree species, this margin is narrow, meaning that tree transpiration operates close to the cavitation induction point (Fig. 11). It may nevertheless be larger in some species like in Cupressus sempervirens [47]. The strategy of maintaining a large safety margin was reported in species experiencing periodically severe drought in their habitat like $J u$ niperus monsperma or Larrea tridentate [109]. At the opposite, in some species cavitation may begin before full stomatal closure like in some poplars [32]. Stomatal control of transpiration appears to be a tool to reduce the risk of deleteri- ous massive embolism in many but not all trees [84, 133, 135]. Stomatal control and hydraulic architecture (i.e., vulnerability to cavitation and hydraulic conductance) are tightly coordinated in many respects (see review by [46]).

\subsection{Water storage capacity in the sapwood}

Water storage capacity in trees is usually rather small when compared to the amount water transpired every day (it could 
sustain 1-2 days of transpiration only). Stored water may contribute to transpiration in trees during diurnal cycles [60] and to the ability of plants to thrive in dry habitats [137]. However, field comparisons of ponderosa pine trees growing in contrasting habitats (desert vs. mountain) did not evidence any difference in water storage between habitats [93]. In pine dominated forests, the strategy in response to increasing atmospheric evaporative demand is to shift the relative allocation to leaves vs. sapwood and therefore to rise $K_{\mathrm{L}}$. However, during long-lasting dry periods, water stored in the sapwood would be significantly reduced and may bring a small contribution to maintaining a positive water balance in trees.

\subsection{Drought effects: species diversity, xylem plasticity and change in biomass allocation}

During periods of low soil water availability, the maintenance of an efficient water transfer from soil to leaves is important for keeping leaf water potential above cavitation thresholds. Indeed, a large $K_{\mathrm{L}}$ corresponds, following the equation $E=K_{\mathrm{L}}\left(\Psi_{\text {soil }}-\Psi_{\mathrm{L}}\right)$, to an improved water sufficiency. A relationship between the annual minimum leaf water potential $\Psi_{\mathrm{L}}$ and $K_{\mathrm{L}}$ has been found in a range of evergreen species [138]. Species with the largest $K_{\mathrm{L}}$ values exhibit also the smallest diurnal variation in $\Psi_{\mathrm{L}}$ and the highest minimum $\Psi_{\mathrm{L}}$ values, At species level, it has been also shown that the conductivity per unit transverse sapwood area $\left(K_{\mathrm{S}}\right)$ increases with decreasing rainfall in deciduous angiosperms, but not in evergreen angiosperms and conifers. These results suggest that increased $K_{\mathrm{S}}$ corresponds to an adaptation of species to water limitation in deciduous angiosperms [94]. This adaptation has been interpreted as a means to maximise water transfer and consequently carbon fixation during periods of large water availability in order to counterbalance drought-imposed periods of latency and stomatal closure. Such an adaptation supports also high transpiration without increasing the water potential gradient and the risk of cavitation [137].

Some degree of phenotypic plasticity in $K_{\mathrm{L}}$ could help to mitigate the effects of drought. Drought frequently results in decreases of xylem conduit dimensions in the short term $[5,45,81,91,128]$. In the long term, the main consequence of drought at tree level is a reduction of sapwood section due to enhanced duraminisation in the sapwood to heartwood transition zone and therefore of $K_{\mathrm{S}}$. Simultaneously, low soil water availability tends to increase $K_{\mathrm{L}}$ through increased root/shoot ratio mainly, or through reduced leaf area. A shift in biomass allocation from foliage to stems and to roots was also found to be driven by increasing vapour pressure deficit [36]. In a recent review, Mencuccini [101] analysed the effects on plant hydraulic conductance of changed environmental conditions: he found that long term drought, fertilization, $\mathrm{CO}_{2}$ enrichment and changes in air vapour pressure deficits had an effect on $K_{\mathrm{L}}$. He concluded that changes in environmental parameter that decreases the availability of resources result in a long term structural acclimation towards a more efficient (per unit leaf area) hydraulic system.
Rood et al. [119] proposed that vulnerability to cavitation and branch dieback are physiologically linked in poplars: drought-induced cavitation underlies branch dieback that reduces transpiration demand enabling the remaining shoot to maintain a favourable water balance. Such an interpretation could be applied to many situations of decline where crown restrictions or crown thinning result from twig abscission, after the onset of severe drought. Klugmann and Roloff [79] suggested that such a process enables pedunculate oak to avoid runaway embolism. Twig shedding and the consequent reduction in whole tree leaf area is usually restricted to older and lateral twigs from the last order of branching. This would enable trees to adjust root-shoot ratios after drought induced decline in root system extent and efficiency. According to this hypothesis, crown thinning could be an acclimation to drought stress [121, 122].

Recent studies have drawn attention on modifications of hydraulic conductance in leaves and roots on a daily or periodic basis by the effect of active processes. Diurnal changes in root hydraulic conductance have been ascribed to changes in plasmalemna or tonoplast aquaporins that act as water channels controlling water fluxes between cells [96, 129]. At leaf level, irradiance dependence of $K_{\mathrm{L}}$ was found to be also driven by aquaporins or hydrogel effect on extravascular (and/or vascular) tissues [145]. Hydraulic resistance in leaves represents an important percentage of tree resistance to water flow and within leaf the main resistance in the liquid phase is extravascular [149]. In Helianthus annuus the contribution of the nonvascular resistance to water transfer amounts to $72 \%$ of whole leaf resistance) [104]. This resistance decreased to $58.4 \%$ in illuminated leaves. Further experimentations are needed to elucidate possible implications of these endogenous factors in response to environmental drought stress.

\subsection{Did the trees undergo important cavitation during the 2003 drought?}

This central question is poorly documented. Indeed, the protection processes (stomatal closure and active leaf shedding) may have been insufficient to prevent xylem water potential from dropping to the cavitation-induction point during peak water deficit mid August 2003. The large twig and leaf shedding observed in several stands may have been preceded by localised cavitation acting as trigger signal for the shedding. Despite the importance of this effect, only few direct observations are available to document this question, probably due to the fact that recording embolism under natural conditions is still a time consuming process, and that seasonal dynamics of embolism are only seldom recorded. Barigah (pers. comm.) detected only limited embolism in beech trees at Hesse during early September 2003, leading to the conclusion that stomatal protection against cavitation was particularly efficient even under severe drought stress. But these results cannot be generalised, and we have to underline the lack of data on this crucial issue. This issue is even more crucial if we tackle the question whether embolism precedes leaf dehydration and 
shedding, and whether it plays a role in subsequent disorders in growth.

There are still open questions to improve our understanding of the importance of hydraulic architecture of trees with regard to ecological distribution of species, or to the definition of functional or botanical groups of species. The importance of hydraulic architecture has only recently been re-evaluated and numerous results are now produced, but there are still large gaps in our knowledge of water transport in trees. Resistance to cavitation is possibly one of the most important parameters determining the degree of drought resistance of a tree [35]. The resistance in the soil-root compartment, as well as the anatomical changes with ageing and in branch junctions (hydraulic bottlenecks) need further researches. Finally, the contribution of hydraulic damages to crown dieback and tree decline remains unclear. Tyree and Zimmermann [149] assessed that "clear proof that xylem embolism (as measured by percent loss conductivity) results in death of plants is hard to establish. This will be a fascinating area of study for future investigations". This holds true and we fully agree with that view.

\section{DELAYED CONSEQUENCES OF DROUGHT}

Irreversible drought-induced damage leads to organ dysfunction, but it only seldom results in direct and immediate induction of tree decline and mortality. Drought induces short term physiological disorders, like decreased carbon and nutrient assimilation, and sometimes even a breakdown of the photosynthetic machinery itself. These tissues have to be repaired before normal processes can resume. In the meantime, the amount of stored carbohydrates is reduced and the storage compartments are not fully refilled at the end of the growing season. The tree must allocate existing stored reserves among the demands for repair, maintenance, growth and defence. Any additional demand on already limited reserves may delay, if not inhibit, recovery of the growth potential. As a consequence, tree ring width or leaf area is frequently smaller during several years following a severe drought $[12,83]$. Moreover, physiological disorders increase tree vulnerability to secondary stresses like insect damage [120], frost or another drought. Fungi may invade weakened trees [37]. Such cumulated processes may lead to long term responses sometimes over several years, and may end either with complete or partial recovery of tree growth, or with final shifts downward a spiral into decline and eventual death. This section discusses the identified and potential physiological mechanisms for such long term responses to a drought event.

\subsection{Delayed effects of drought on wood, leaf and fruit production}

Available water, more than any other resource, determines the annual growth potential of individual trees. Variations in water availability account for up to $80 \%$ of the inter-annual variability in size increment in temperate stands. Tree water deficits dramatically reduce both height and radial growth as well as bud production. Twig growth patterns are affected during several years, as demonstrated by Stribley and Ashmore [139] for beech in southern Great Britain: recovery from the 1990 drought was still not complete when the 1995 drought began, and induced even further growth suppression. Such a reduction of twig growth over several years after drought was already mentioned for beech [112]. Dendrochronological studies also detected large delayed effects of water availability on ring width, which reached up to six years for silver fir in the Vosges Mountains [14]. Such a long "memory" for fir may be due to the length of needle retention, lasting more than 10 years under optimal growth conditions.

In many tree species, environmental conditions during the year of bud formation can control following year's shoot length to a greater degree than the environmental conditions during the year of shoot expansion. Shoot formation in trees is frequently a two-year process involving bud development the first year and extension of organs within the bud during the second year. Drought during the year of bud formation decreases the number of new leaves formed in the bud and the new stem segments (internodes) present. Drought then influences the number of leaves, leaf surface area, and twig extension the following year when those buds expand [33]. Summer droughts can greatly reduce shoot elongation in species that exhibit continuous growth or multiple flushing. Drought may not inhibit the first growth flush that usually occurs before peak drought intensity, but may decrease the number of stem units formed in the new bud that will expand during the second (or third, etc.) flush of growth. If drought continues, all growth flushes will be affected.

As a consequence, severe drought limits leaf area production by reducing the number and viability of leaf buds and thus the tree's ability to recover an efficient crown development after resuming normal water availability. As a result, at stand level, leaf area index may be reduced by as much as $2-3$ the year following a severe drought $[1,12,83]$, without any tree mortality, and the recovery of LAI to pre-drought levels may require several years. Leaf area index of coniferous stands may also decrease after severe drought, due to an abnormal shedding of older needles. Such a reduction in tree leaf area has also been reported from crown transparency observations, as used for tree vitality assessment in the European Forest condition monitoring (Level 1) Network [75]. Increasing evidence is gathered from the permanent monitoring plots elsewhere in Europe illustrating that the loss of leaves/needles is a frequent response to limiting soil water and drought is a self-sufficient explanation to the observed crown condition for both Abies and Picea [153] or Pinus [111] in Switzerland.

We quantified the direct impact of the exceptional 2003 drought on beech canopy leaf area index in Eastern France. In fact, it was the first time, over a 30 year-period (since 1976, [9]), that we measured a direct reduction of canopy leaf area index due to premature leaf shedding during August. The fallen leaves were still green (Fig. 12): no yellowing and probably no nutrient remobilization occurred before shedding: petioles were probably embolized, but only a very small loss of conductivity was detected on current year twigs (Barigah, pers. comm). Some dehydrated leaves were also still attached 

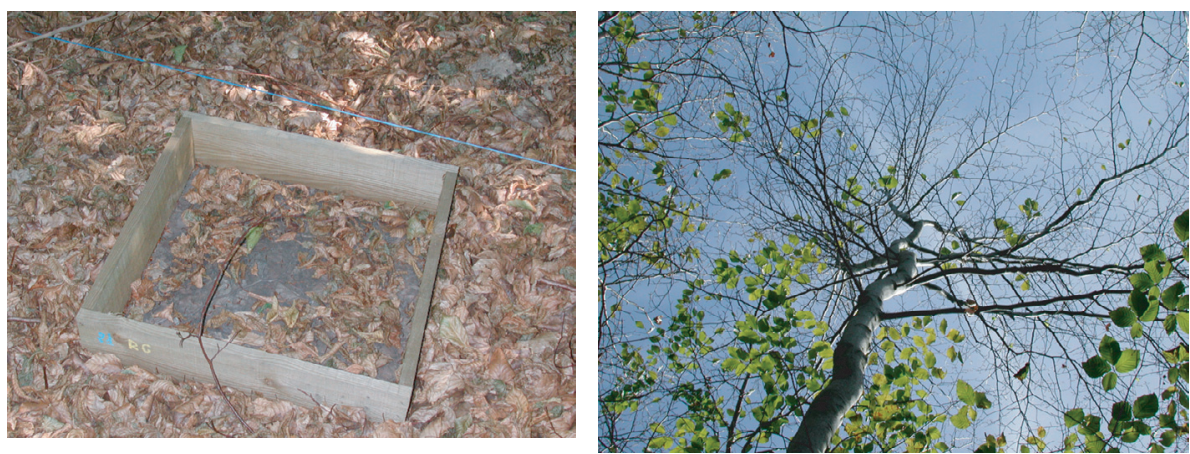

Figure 12. Premature leaf fall during August 2003 in the beech stand at Hesse. Note that green leaves are collected and that some trees are totally defoliated. (Pictures N. Bréda.)

Table I. Concentration in starch, soluble sugars and Total Nonstructural Carbohydrates (TNC) (gC/100 gMS) in the wood at collar of beech trees (Fagus sylvatica) from the Carboeurope site of Hesse (Eastern-France); wood samples were collected in October 2003; 34 couples of adjacent leafed beech and premature drought-defoliated beech trees during August 2003. (N. Bréda, original results).

\begin{tabular}{lccc}
\hline & Starch & Sugars & TNC \\
\hline Leafed trees & $1.56(0.08)$ & $1.89(0.06)$ & $3.46(0.12)$ \\
Drought-defoliated trees & $0.74(0.14)$ & $2.01(0.05)$ & $2.75(0.009)$ \\
Probability for significant & 0.0001 & 0.127 & 0.0001 \\
differences & & & \\
\hline
\end{tabular}

to the twigs, and were brown like if oven-dried as a result of excess heat. From the hydraulic point of view, perennial organs were protected from damages. This spectacular protection against hydraulic damage through premature leaf fall had no consequence on visual assessment of crown condition the next summer in beech that recovered to normal values [105]. But carbon balance of the "defoliated" trees was affected as evidenced from a significant reduction of starch content, and of total non structural carbohydrates at the end of the 2003's growing season (Tab. I).

Such an exceptional reduction of leaf area index had never been observed before for beech; it reached $4 \mathrm{~m}^{2} \cdot \mathrm{m}^{-2}$ at some places in the stands. Within the two prospected forest stands (40 ha), the decrease of LAI measured between June 2003 and August 2003 was tightly related to the soil water deficit, as quantified by a soil water deficit index (see above) (Fig. 13). Nevertheless, the impact of a large soil water deficit on leaf area index was variable among species: beeches and hornbeam were completely and partly defoliated respectively, while oaks were not at all.

Drought modifies carbon allocation among leaf, root and wood growth, carbohydrate storage and fruiting. This latter function is probably the least documented up to now in forest trees. During an ecosystem manipulation experiment in a 60 year old Norway spruce stand, no significant difference was observed in cone formation between droughted and control plots [40]. The European Network for Forest Health Monitoring produces inter-annual monitoring data for fruit and flower

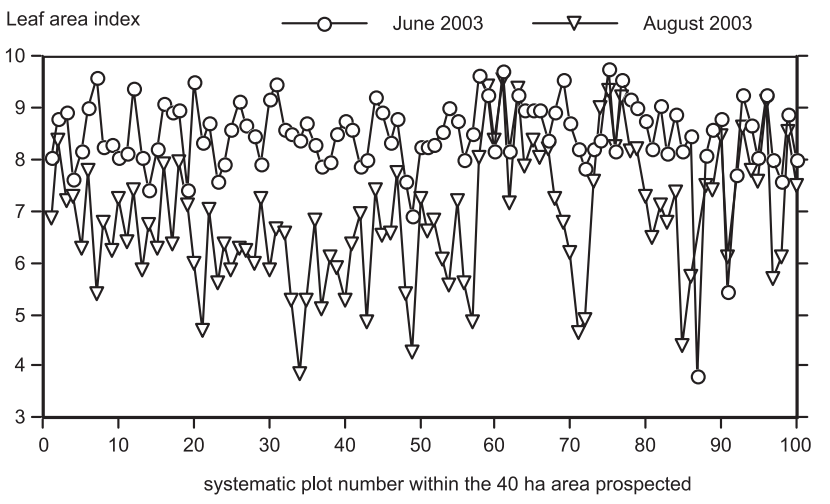

(a)

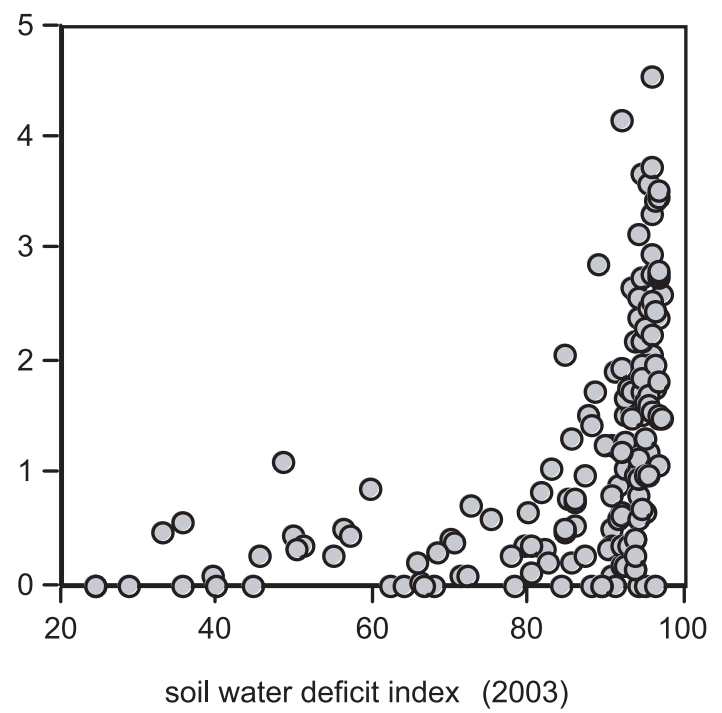

(b)

Figure 13. Example of leaf area reduction as a result of the 2003 drought in 35 -y-old beech stands, Hesse Forest, France. (a) LAI was measured in systematic plots using two inter-calibrated LAI-2000 (Li-Cor, Nebraska, USA) twice during the growing season: after total leaf expansion (Mid June) and after premature drought-induced leaf fall (end of August). (b) The reduction of LAI is related to soil water deficit calculated for each plot, according to its June LAI and its soil properties, using the daily water balance model BILJOU [55]. 
compartments in annual litter return. Such data allow the detection of potential heavy mast production years. Seed production may be increased by drought, but often drops during the two to three years following a drought. Such an observation was reported for beech after the 1989 drought in Britain [66, 70]. More recently in Germany, Eichhorn et al. [43] showed that over $80 \%$ of the beech trees exhibited a heavy mast production during 2004, which was the highest figure since 1990. As a consequence of higher mast production, leaf area is reduced and crown transparency increases. However, it is not clear whether the process that triggers the drought-induced flowering and seed production also triggers the dieback or whether the relationship between dieback and fruit production is directly causal [70]. Controversial observations were reported for beech vs. spruce or Scots pine. In any case, drought induces pluri-annual changes in carbon allocation which have to be considered as a normal and reversible regulation process. Only site predisposition or concomitant biotic invasions may turn the process into irreversible situations for some trees. The following section discusses this point.

Besides plant growth and tissue maintenance, carbohydrates are used to form the basis of lipids, proteins, growth regulators and many secondary metabolites [80]. Secondary metabolites include tannins and alkaloids that are involved in defence. As the production of these compounds decreases, trees become more susceptible to attack by opportunistic insects [41] and fungal organisms [152]. If there are clear demonstrations of enhanced success of direct attacks by insect pests and disease organisms on drought-weakened trees [151] in comparison to healthy trees [37], the time lag in the interactions between secondary pests and drought-induced predisposition is still not clearly established on mature trees.

\subsection{Drought induced mortality}

The severe and long 2003 drought that produced stress symptoms in many trees (premature leaf fall, yellowing, shedding), resulted in large numbers of individuals being in a weakened condition, i.e. with low radial growth and small amounts of stored carbohydrates. Unfortunately, in a large area in Europe, the weather was not favourable during 2004 and 2005 with new drought episodes. Some trees may begin to decline if they were already stressed prior to the 2003's drought [15]. If the trees have been predisposed to stress because of poor growing conditions, site disturbance or a history of damage, they may die this year or next year without exhibiting visible warning signals. Foresters and plant health specialists have reported partial bud break, scattered mortality of adult trees and significant mortality in some young plantations. During spring 2004 and 2005, a number of trees began to leaf out as usual, but stopped mid-stream. Then individual branches and/or whole trees died. As an example, a spectacular increase of mortality rates was reported during 2004 in the French part of the European (Level I) Network for Forest Condition Assessment. Mortality rose from $0.2 \%$ up to $0.5 \%$ for broadleaved species or up to $1.2 \%$ for coniferous trees [118]. Petersen [106] suggested that the mortality of oaks can be used as a bioindicator of environmental stress, especially drought. Jenkins and Pallardy [74] demonstrated a persistent effect involving long term reduction in the sensitivity of red oak growth to climate. They emphasize the role of severe droughts in predisposing trees to eventual death.

Drought has been frequently involved in forest decline over Europe and North America with death of individual trees or small clusters of trees creating canopy gaps $[27,78]$. The implication of drought in oak stand decline was demonstrated in France (after the 1976' drought [13], after the 1989-1991 dry sequence [20]), in Poland [130], and in all Central Europe wide [142]. Nevertheless, the latter authors proposed a conceptual model of the interaction of abiotic (drought) and biotic factors (defoliation for two consecutive years) responsible for the onset of oak decline. Some additional stress factors like soil hydromorphy or nitrogen excess could also be involved in the process. A growing body of evidence in the literature supports the notion that the risk of tree death increases with a decreasing growth rate [107, 140]. Wyckoff and Clark [155], using various growth-mortality functions, showed that dead trees of Cornus florida and Acer rubrum exhibited lower growth rates during the 5 years prior to mortality than surviving ones. Furthermore, they examined the effect of tree size on growthmortality functions and found that the rate of mortality was driven by tree size. Finally poor crown conditions, possibly induced by drought, are also linked to the probability for a tree to die $[39,131]$. Such a decrease in radial or length growth before death is frequently reported, but is not responsible for tree death. The more probable functional explanation is that growth is an indicator of tree carbon balance dysfunction, and mortality is very likely caused by reserve depletion.

In most tree-decline studies, a tight correlation was observed between the occurrence of drought and tree mortality, including differential mortality among tree species [103]. Nevertheless, there is really a lack of more mechanistic approaches, able to identify the critical mechanisms underlying this correlation. Two kinds of mechanism are suggested from the literature: a hydraulic dysfunction [109] or a deficit in carbon balance [154], due either to a too severe reduction of leaf area or to a deficit of storage compounds. From an ecophysiological point of view, both hypotheses are coupled through stomatal control and water use efficiency. The close connection between the water and carbon hypotheses was recently used by Martinez-Vilalta et al. [95] to model drought-induced mortality. They proposed a hydraulic model to predict drought-induced mortality of woody species assuming that plant mortality is controlled by the carbon balance: when the plant is unable to transfer water because of xylem embolism, is ceases to acquire carbon, and if the situation lasts long enough, it can no longer survive. This hypothesis is based on experimental observations after the exceptionally dry 1994 year in Spain, in some Quercus ilex populations the amount of individual that dried completely was up to $80 \%$, while Phillyrea latifolias survived. The model uses morphology of the root system, sap flux and leaf water potential, which allows calculating a percent loss of conductivity, inducing itself a reduction of leaf area. When leaf area is reduced below $5 \%$ of initial leaf area for a critical time, mortality 


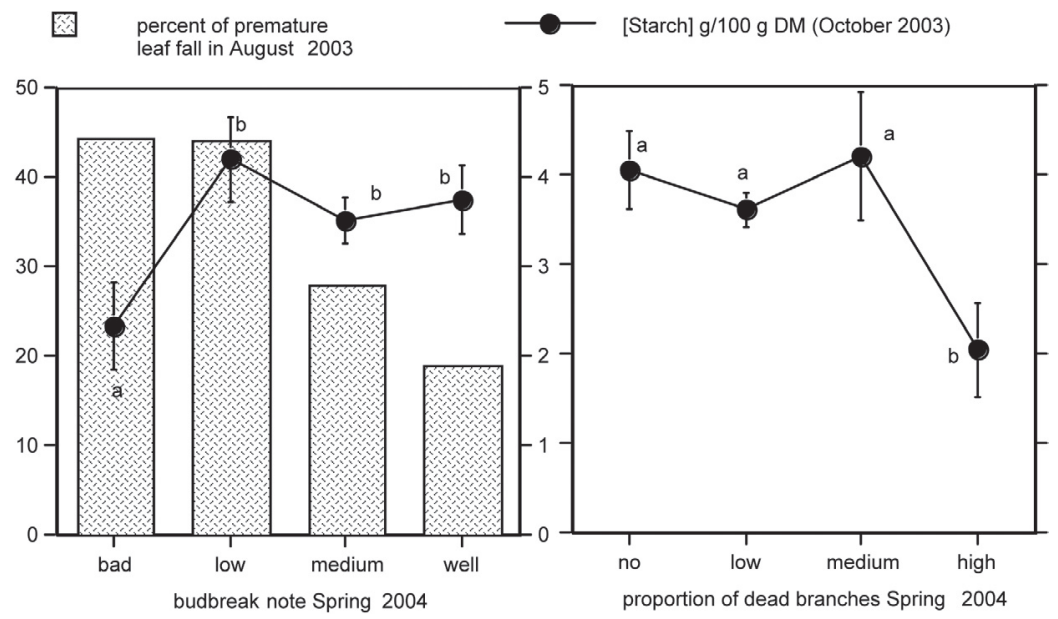

Figure 14. Left: phenology of oaks during spring 2004 (four categories: bad, low, medium and optimal) according to the percent of premature leaf fall during August 2003 and starch content in wood sampled from the collar (g per $100 \mathrm{~g}$ dry matter) measured during October 2003. Right: proportion of dead branches observed during spring 2004 according to the starch content recorded during October 2003. Vertical bars are standard errors, $n=194$ oaks from the Harth Forest, France. (N. Bréda, original data.)

occurs. Interestingly, recurrent droughts can produce a progressive loss of resilience, by depleting the ability of surviving plants to regenerate [88].

There is increasing evidence supporting the occurrence of hydraulic constraints within the soil-plant-atmosphere continuum (SPAC) as a limit for different plant species to cope with water stress [109]. As a result of sharp increases in soil water potential during drought progression, both absorption and transfer of water are disrupted so that maintaining a hydraulic continuum within the tree is a real challenge: (1) there is an exponential increase of in soil and soil-to-root resistance to water as soil dries, limiting water uptake; (2) the occurrence of cavitation inside the xylem increases as leaf water potential decreases, limiting or even stopping water transfer. As shown previously, one of the possible induced consequences is the reduction of leaf area, which in turn reduces carbon fixation after soil re-watering, and then inducing growth reduction [17].

The carbon hypothesis, based on carbohydrates and other storage compound deficiency, is supported by the time-lag between drought event and tree decline or mortality. Because a deficiency in stored reserves may last one or several years after a stress event, related damage may not become evident that year. That can make diagnosis of the causes of tree decline very difficult, and a retrospective view of tree history by the way of dendrochronology is often helpful. If the impact of drought on stomatal control, carbon assimilation and water use efficiency is well established, few data are available to support the hypothesis of a deficit in the replenishment of carbohydrate storage. Such an effect may have consequences on tree cold hardiness, defence against pathogens, ability to ensure maintenance respiration during the winter time, leaf area expansion... At the end of the 2003's growing season, we measured starch concentrations in oaks from a very dry forest and checked for the relationships between starch content at the of 2003 and crown conditions during Spring 2004. Figure 14 shows that (1) bud break during Spring 2004 was af- fected by the premature drought-induced leaf fall during Summer 2003 and by the starch content of trees at the end of the growing season, (2) the amount of dead branches and twigs in spring 2004 is the highest for oaks exhibiting the lowest starch content at the end of the season 2003. These observations illustrate the one-year delay in the impact of drought via the amount of carbohydrate reserve on the crown vitality of oak during the following year. The weakness hypothesis based on carbohydrate stores as a measure of host strength seems to be confirmed by this example from oaks. But the observation of these trees has to be pursued during coming years; unfortunately complex interactions with heavy defoliations in Spring 2004 and root pathogens will probably impact too the amount stored compounds $[37,59]$.

\section{CONCLUSIONS: NEW CHALLENGES FOR SCIENTISTS}

During the course of the 21st century, the global-average surface temperatures will likely increase by $2-4.5{ }^{\circ} \mathrm{C}$. At the same time there will be changes in precipitation regimes in Western Europe with probably larger winter rains and more severe precipitation deficits during summer. We focused the review on the temperate European forests, because they will probably be the most affected by drought, either during exceptional events (e.g. the year 2003), or under a long-term drift towards more arid conditions as exists today in the Mediterranean areas. Extreme climatic events such as heat waves and drought episodes like those experienced during summer 2003 are expected to occur at increased frequencies in these regions. Severe and recurrent droughts have been identified as a major contributing factor in the recently accelerated rates of tree decline and mortality in Europe. Diffuse tree mortality within forest stands has frequently been reported after such an extreme event. This diffuse mortality may be related to local 
variability in soil properties (mainly local water storage capacity) or to genetic diversity among and within tree species. Indeed, such mortality can be regarded as the expression of a selection process against sensitivity to drought.

Significant improvement of our understanding of water relations of trees and forest stands, in both liquid and vapour phases, has been achieved since the last extreme drought events (1976, 1989-1991), even if the research focus over the last years was mainly on the role of forests in the global carbon balance. During the last decade, the importance of the interspecific diversity of the coupling between hydraulic architecture in trees and stomatal control of transpiration has been particularly well documented. The 2003's drought and its impact on the European Forest was an opportunity to recall that water shortage is not only the most likely cause of inter-annual changes in primary productivity of forests but may also compromise tree health and survival. Nevertheless, we still need a truly mechanistic approach to analyse the suspected causes for tree death; such an approach should take into account the complex interactions among depleted carbohydrate stores in trees, decreased water transport efficiency and pest and disease outbreak affecting weakened trees.

Further research is needed to model the water stress intensity really experienced by trees as well as interspecific differences in the way trees experience local water deficits and adjust to them. The permanent wilting point, which was defined by agronomists as the soil water potential threshold for water absorption by roots, has to be adapted to tree species. Trees are, on average, characterized by the ability to extract water at water potentials below this threshold. Research is also needed (i) to demonstrate the direct involvement of drought induced damages in the soil-root compartment, (ii) to test for the implication of embolism and xylem dysfunctions in tree death, and (iii) to identify the physiological processes explaining the time lag between drought and tree decline. There is obviously a large inter and intra-specific diversity in traits related to water use and coupling of water use and carbon assimilation (i.e., water use efficiency) that needs be assessed, and the implication of such traits in the overall tolerance to drought needs be investigated on the basis of whole tree, functional models. Moreover, special attention should be paid to the physiological processes affected by recurrent drought years and resulting in reduced tree growth and health during several years. Changes in water and carbon cycles due to drought have to be analysed among tree species and over several years to detect potential changes in carbon allocation to tree compartments and to physiological functions (respiration, growth, storage). Other processes related to the short and long term acclimation of trees to drought need be better understood. Finally, nitrogen nutrition and cycling is likely to be modified by drought [48], and the impact of nutrient shortage under water deficit has to be quantified under various levels of site fertility and among drought tolerant, resistant or avoiding tree species.

\section{REFERENCES}

[1] Aber J.S., Wallace J., Nowak M.C., Response of forest to climatic events and human management at Fort Leavenworth, Kansas, Curr. Res. Earth Sci. Bull. 248 (2002) 1-24.
[2] Ameglio T., Bodet C., Lacointe A., Cochard H., Winter embolism, mechanisms of xylem hydraulic conductivity recovery and springtime growth patterns in walnut and peach trees, Tree Physiol. 22 (2002) 1211-1220.

[3] Ameglio T., Cochard H., Picon C., Cohen M., Water relations and hydraulic architecture of peach trees under drought conditions, in: Monet R. (Ed.), Proc. Fourth Intern. Peach Symposium, Acta Hortic. 465 (1998) 355-361.

[4] Angeles G., Bond B., Boyer J.S., Bodribb T., Burns M.J., Cavender-Bares J., Clearwater M., Cochard H., Comstock J., Domec J.C., Donovan L., Ewers F., Gartner B., Hacke U., Hinckley T., Holdbrook N.M., Jones H.G., Lopez-Portillo J., Lovisolo C., Martin T., Martinez-Vilalta J., Mayr S., Meinzer F.C., Melcher P., Mencuccini M., Mulkey S., Nardini A., Neufeld H.S., Passioura J., Pockman W.T., Pratt R.B., Rambal S., Richter H., Sack L., Salleo S., Schubert A., Schulte P., Sparks J.P., Sperry J., Teskey R., Tyree M., The Cohesion-Tension Theory, New Phytol. 163 (2004) 451-452.

[5] Arnold D.H., Mauseth J.D., Effects of environmental factors on development of wood, Am. J. Bot. 86 (1999) 367-371.

[6] Aussenac G., Action du couvert forestier sur la distribution au sol des précipitations, Ann. Sci. For. 27 (1970) 383-399.

[7] Aussenac G., Boulangeat C., Interception des précipitations et évapotranspiration réelle dans des peuplements de feuillus (Fagus silvatica L.) et de résineux (Pseudotsuga menziesii (Mirb.) Franco), Ann Sci. For. 37 (1980) 91-107.

[8] Aussenac G., Granier A., Ibrahim M., Influence du dessèchement du sol sur le fonctionnement hydrique et la croissance du Douglas (Pseudostuga menziesii (Mirb.) Franco, Acta Oecol., Oecol. Plant. 5 (1984) 241-253.

[9] Aussenac G., La sécheresse de 1976 : influence des déficits hydriques sur la croissance des arbres forestiers, Rev. For. Fr. XXX (1978) 103-114.

[10] Aussenac G., Interactions between forest stands and microclimate: Ecophysiological aspects and consequences for silviculture, Ann. For. Sci. 57 (2000) 287-301.

[11] Barataud F., Moyne C., Bréda N., Granier A., Soil water dynamics in an oak stand. II. A model of the soil-root network compared with experimental data, Plant Soil 172 (1995) 29-43.

[12] Battaglia M., Cherry M.L., Deadle C.L., Sands P.J., Hingston A., Prediction of leaf area index in eucalypt plantations: effect of water stress and temperature, Tree Physiol. 18 (1998) 521-528.

[13] Becker M., Lévy G., Le dépérissement du chêne en forêt de Tronçais : les causes écologiques, Ann. Sci. For. 39 (1982) 439_444.

[14] Becker M., The role of climate on present and past vitality of silver fir forests in the Vosges mountains of northeastern France, Can. J. For. Res. 19 (1989) 1110-1117.

[15] Beniston M., Innes J.L., Impacts of climatic variability and extreme on forests: synthesis, in: Beniston M., Innes J.L. (Eds.), The impacts of climate variability on forest, Lecture Notes in Earth Sciences No. 74, Springer (1998) 309-318.

[16] Bishop K., Dambrine E., Localization of tree water uptake in Scots pine and Norway spruce with hydrological tracers, Can. J. For. Res. 25 (1995) 286-297.

[17] Borghetti M., Cinnirella S., Magnani F., Saracino A., Impact of long-term drought on xylem embolism and growth in Pinuns halepensis Mill., Trees, Trunc. Funct. 12 (1998) 187-195.

[18] Boyd R., Furbank R.T., Read D., Ectomycorrhiza and the water relations of trees, in: Gianinazzi-Pearson V., Gianinazzi S. (Eds.), Physiological and genetical aspects of mycorrhizae, Éditions INRA, Paris, France, 1986.

[19] Bréda N., Granier A., Barataud F., Moyne C., Soil water dynamics in an oak stand. I. Soil moisture, water potentials and water uptake by roots, Plant Soil 172 (1995) 17-27. 
[20] Bréda N., Water shortage as a key factor in the case of oak dieback in the Forêt de la Harth (Alsacian plain, France), in: Oszako T., Delatour C. (Eds.), Recent Advances on Oak Health in Europe, International Conference, 22-24 November 1999, Warsaw, Poland, (2000) pp. 157-160.

[21] Brodribb T., Hill R.S., The importance of xylem constraints in the distribution of conifer species, New Phytol. 143 (1999) 365-372.

[22] Brunel J.P., Walker G.R., Dighton J.C., Monteny B., Use of stable isotopes of water to by the vegetation and to partition evapotranspiration. A case study from HAPEX Sahel, J. Hydrol. 189 (1997) 466-481.

[23] Buée M., Vairelles D., Garbaye J., Year-round monitoring of diversity and potential metabolic activity of the ectomycorrhizal community in a beech (Fagus silvatica) forest subjected to two thinning regimes, Mycorrhiza 15 (2005) 235-245.

[24] Burgess S.S.O., Pate J.S., Adams M.A., Dawson T.E., Seasonal water acquisition and redistribution in the Australian woody phreatophyte, Banksia prionotes, Ann. Bot. 85 (2000) 215-224.

[25] Ciais P., Viovy N., Reichstein M., Granier A., Ogée J., Rambal S., Ourcival J.M., Bernhofer C., Grunwald T., Pilegaard K., Berbigier P., Vesala T., Aubinet M., Heinesch B., Loustau D., Seufert G., Manca G., Matteucci G., Miglietta F., Soussana J.F., Knohl A., Sanz M.J., Carrara A., Friend A., Chevallier F., Schulze E.D., Valentini R., An unprecedented reduction in the primary productivity of Europe during 2003 caused by heat and drought, Nature 03972 (2005) 529-533.

[26] Clearwater M.J., Goldstein G., Embolism repair and long distance water transport, in: Holbrook N.M., Zwieniecki M.A. (Eds.), Vascular transport in plants, Elsevier Academic Press, Burlington, 2005, pp. 375-400.

[27] Clinton B.D., Boring L.R., Swank W.T., Canopy gap characteristics and drought influences in oak forests of the Coweeta basin, Ecology 74 (1993) 1551-1558.

[28] Cochard H., Bréda N., Granier A., Whole-tree hydraulic conductance and water loss regulation of Quercus petraea during drought: evidence for stomatal control of embolism? Ann. Sci. For. 53 (1996) 197-206.

[29] Cochard H., Froux F., Mayr S., Coutand C., Xylem wall collapse in water-stressed pine needles, Plant Physiol. 134 (2004) 401-408.

[30] Cochard H., Lemoine D., Améglio T., Granier A., Mechanisms of xylem recovery from winter embolism in Fagus sylvatica, Tree Physiol. 21 (2001) 27-33.

[31] Cochard H., Lemoine D., Dreyer E., The effects of acclimation to sunlight on the xylem vulnerability to embolism in Fagus sylvatica L., Plant Cell Environ. 22 (1999) 101-108.

[32] Cochard H., Ridolfi M., Dreyer E., Responses to water stress in an ABA-unresponsive hybrid poplar. 2. Hydraulic properties and xylem embolism, New Phytol. 134 (1996) 455-461.

[33] Coder K.D., Drought Damage to Trees, 1999, available at http://www.dnr.state.mn.us/fid/oct03/droughtstress.html.

[34] Coners H., Leuschner C., In situ water absorption by tree fine roots measured in real time using miniature sap-flow gauges, Funct. Ecol. 16 (2002) 696-703.

[35] Cruiziat P., Cochard H., Ameglio T., Hydraulic architecture of trees: main concepts and results, Ann. For. Sci. 59 (2002) $723-$ 752.

[36] DeLucia E.H., Maherali H., Carey E.V., Climate-driven changes in biomass allocation in pines, Glob. Change Biol. 6 (2000) 587-593.

[37] Desprez-Loustau M.L., Marçais B., Nageleisen L.M., Piou D., Vanini A., Interactive effects of drought and pathogens in forest trees, Ann. For. Sci. 63 (2006) 595-610.

[38] Dixon H.H., Joly J., On the ascent of sap, Philos. Trans. R. Soc. London B186: (1895) 563-576.

[39] Dobbertin M., Brand P., Crown defoliation improves tree mortality models, For. Ecol. Manage. 141 (2001) 271-284.
[40] Dohrenbusch A., Jaehne S., Bredemeier M., Lamersdorf N., Growth and fructification of a Norway spruce (Picea abies L. Karst.) forest ecosystem under changed nutrient and water input, Ann. For. Sci. 59 (2002) 359-368.

[41] Dunn J.P., Potter D.A., Kimmerer T.W., Carbohydrate reserves, radial growth and mechanisms of resistance of oak trees to phloemboring insects, Oecologia 83 (1990) 458-468.

[42] Ehleringer J.R., Dawson T.E., Water uptake by plants: perspectives from stable isotope composition, Plant Cell Environ. 15 (1992) 1073-1082.

[43] Eichhorn J., Aamlid D., Bastrup-Birk A., Dobbertin M., Durrant D., Ferretti M., Mues V., Neumann M., Rautio P., Roskams P., Sanchez G., Solberg S., Szepesi A., Tree reaction on stress factors. Concept and results of 20 years ICP Forests, 21stTask Force Meeting of ICP Forests, 23-26 May (2005), Rome, Italy.

[44] Eissenstat D.M., Wells C.E., Yani R.D., Whitbeck J.L., Building roots in a changing environment: implication for root longevity, New Phytol. 147 (2000) 33-42.

[45] February E., Manders P., Effect of water supply and soil type on growth, vessel diameter and vessel frequency in seedlings of three fynbos shrubs and two forest trees, S. Afr. J. Bot. 65 (1999) 382387.

[46] Franks P., Brodribb T.J., Stomatal control and water transport in the xylem, in: Holbrook N.M., Zwieniecki M.A. (Eds.), Vascular transport in plants, Elsevier Academic Press, Burlington, 2005, pp. 69-89.

[47] Froux F., Huc R., Ducrey M., Dreyer E., Xylem hydraulic efficiency versus vulnerability in seedlings of four contrasting Mediterranean tree species (Cedrus atlantica, Cupressus sempervirens, Pinus halepensis and Pinus nigra), Ann. For. Sci. 59 (2002) 409-418.

[48] Gessler A., Keitel C., Nahm M., Rennenberg H., Water shortage affects the water and nitrogen balance in Central European beech forests, Plant Biol. 6 (2004) 289-298.

[49] Garbaye J., Churin J.L., Growth stimulation of young oak plantations inoculated with the ectomycorrhizal fungus Paxillus involutus with special reference to summer drought, For. Ecol. Manage. 98 (1997) 221-228.

[50] Garnier E., Berger A., Rambal S., Water balance and pattern of soil water uptake in a peach orchard, Agric. Water Manage. 11 (1988) 145-158.

[51] Gartner B.L., Roy J., Huc R., Effects of tension wood on specific conductivity and vulnerability to embolism of Quercus ilex seedling grown at two atmospheric $\mathrm{CO}_{2}$ concentrations, Tree Physiol. 23 (2003) 387-395.

[52] Gash J.H.C., An analytical model of rainfall interception by forest, Q. J. R. Meteorol. Soc. 105 (1979) 43-55.

[53] Gash J.H.C., Wright I.R., Llyod C.R., Comparative estimates of interception loss from three coniferous forests in Great Britain, J. Hydrol. 38 (1980) 89-105.

[54] Goldstein A.H., Hultman N.E., Fracheboud J.M., Bauer M.R., Panek J.A., Xu M., Qi Y., Guenther A.B., Baugh W., Effects of climate variability on the carbon dioxide, water, and sensible heat fluxes above a ponderosa pine plantation in the Sierra Navada (CA), Agric. For. Meteorol. 101 (2000) 113-129.

[55] Granier A., Bréda N., Biron P., Villette S., A lumped water balance model to evaluate duration and intensity of drought constraints in forest stands, Ecol. Model. 116 (1999) 269-283.

[56] Granier A., Loustau D., Bréda N., A generic model of forest canopy conductance dependent on climate, soil water availability and leaf area index, Ann. For. Sci. 57 (2000) 755-765.

[57] Granier A., Loustau D., Measuring and modelling the transpiration of a maritime pine canopy from sap-flow data, Agric. For. Meteorol. 71 (1994) 61-81. 
[58] Granier A., Reichstein M., Grünwald T., Berbigier P., Heinesch B., Knohl A., Köstner B., Longdoz B., Loustau D., Pilegaard K., Tenhunen J., Vesala T., Wang Q., The drought of 2003 in Western Europe: consequences on forest ecosystems functioning, http://www.gip-ecofor.org/.

[59] Griffin D.H., Manion P.D., Kruger B.M., Mechanisms of 'disease' predisposition by environmental stress, in: Recent Advances in Studies on Oak Decline, Brindisi, Italy, 13-18, 1992, pp. 123-138.

[60] Grote R., Suckow F., Integrating dynamic morphological properties into forest growth modelling I. Effects on water balance and gas exchange, For. Ecol. Manage. 112 (1998) 101-119.

[61] Guehl J.M., Garbaye J., The effect of ectomycorrhizal status on carbon dioxide assimilation capacity, water-use efficiency and response to transplanting in seedlings of Pseudotsuga menziesii (Mirb.) Franco, Ann. Sci. For. 21 (1990) 551-563.

[62] Guehl J.M., Garbaye J., Wartinger A., The effect of ectomycorrhizal status on plant water relations and sensitivity of leaf gas exchange to soil drought in Douglas fir (Pseudotsuga menziesii) seedlings, in: Read D.J., Lewis D.H., Fitter A.H., Alexander I.J. (Eds.), Mycorrhizas in Ecosystems, CAB International, UK (1992) 323-332.

[63] Hacke U., Sauter J.J., Drought-induced xylem dysfunction in petioles, branches, and roots of Populus balsamifera L. and Alnus glutinosa (L.) Gaertn., Plant Physiol. 111 (1996) 413-417.

[64] Hacke U.G., Sperry J.S., Functional and ecological xylem anatomy, Perspect. Plant Ecol. Evol. Syst. 4 (2001) 97-115.

[65] Hacke U.G., Sperry J.S., Pockman W.T., Davis S.D., McCulloh K.A. Trends in wood density and structure are linked to prevention of xylem implosion by negative pressure, Oecologia 126 (2001) 457-461.

[66] Hendry S.J., Boswell R.C., Proudfoot J.C., Forest condition 2000 , 2001, http://www.forestry.gov.uk

[67] Holbrook N.M., Ahrens E.T., Burns M.J., Zwieniecki M.A., In vivo observation of cavitation and embolism repair using magnetic resonance imaging, Plant Physiol. 126 (2001) 27-31.

[68] Holbrook N.M., Zwieniecki M.A., Embolism repair and xylem tension: do we need a miracle? Plant Physiol. 120 (1999) 7-10.

[69] Hukin D., Cochard H., Dreyer E., Le Thiec D., Bogeat-Triboulot M.B., Cavitation vulnerability in roots and shoots: does Populus euphratica Oliv., a poplar from arid areas of Central Asia, differ from other poplar species? J. Exp. Bot. 56 (2005) 2003-2010.

[70] Innes J.L., The occurrence of flowering and fruiting on individual trees over 3 years and their effects on subsequent crown condition, Trees Struct. Func. 8 (1994) 139-150.

[71] IPCC Climate change 2001: the scientific basis, 2001, http://www.ipcc.ch/.

[72] Jackson R.B., Sperry J.S., Dawson T.E., Root water uptake and transport: using physiological processes in global predictions, Trends Plant Sci. 5 (2000) 482-488.

[73] Jany J.L., Martin F., Garbaye J., Respiration activity of ectomycorrhizas from Cenococcum geophilum and Lactarius sp. in relation to soil water potential in five beech forests, Plant Soil 255 (2003) 487-494.

[74] Jenkins M.A., Pallardy S.G., The influence of drought on red oak group species growth and mortality in the Missouri Ozarks, Can. J. For. Res. 25 (1995) 1119-1127.

[75] Jewell N., Kennedy P., Analysis of European Forest condition data base, EUR 19803 - Luxembourg: Office for Official Publications of the European Communities, 2001, $48 \mathrm{p}$.

[76] Jones H.G., Sutherland R.A., Stomatal Control of Xylem Embolism, Plant Cell Environ. 14 (1991) 607-612.

[77] Kavanagh K.L., Bond B.J., Aitken S.N., Gartner B.L., Knove S., Shoot and root vulnerability to xylem cavitation in four populations of Douglas-fir seedlings, Tree Physiol. 19 (1999) 31-37.
[78] Kloeppel B.D., Clinton B.D., Vose J.M., Cooper A.R., Drought impacts on tree growth and mortality of southern Appalachian forests, in: Greenland D., Goodin D.G., Smith R.C. (Eds.), Climate Variability and Ecosystem Response at Long-Term Ecological Research Sites, Oxford University Press, New York, 2003, pp. $43-55$.

[79] Klugmann K., Roloff A., Twig abscission (cladoptosis) and its ecophysiological significance for decline symptoms in Quercus robur L., Forestw. Cbt. 118 (1999) 271-286.

[80] Kramer P.J., Kozlowski T.T., Physiology of trees, McGraw-Hill Book Inc., New York, 1960, 642 p.

[81] Ladjal M., Huc R., Ducrey M., Drought effects on hydraulic conductivity and xylem vulnerability to embolism in diverse species and provenances of Mediterranean cedars, Tree physiol. 25 (2005) 1109-1117.

[82] Law B., Falge E., Gu L., Baldocchi D.D., Bakwin P., Berbigier P., Davis K.J., Dolman A.J., Falk M., Fuentes J.D., Goldstein A.H., Granier A., Grelle A., Hollinger D., Janssens I.A., Jarvis P.G., Jensen N.O., Katul G., Mahli Y., Matteucci G., Meyers T., Monson R.K., Munger J.W., Oechel W., Olson R., Pilegaard K., Paw U.K.T., Thorgeirsson H., Valentini R., Verma S., Vesala T., Wilson K., Wofsy S., Environmental controls over carbon dioxide and water vapor exchange of terrestrial vegetation, Agric. For. Meteorol. 113 (2002) 97-120.

[83] Le Dantec V., Dufrêne E., Saugier B., Interannual and spatial variation in maximum leaf area index of temperate deciduous stands, For. Ecol. Manage. 134 (2000) 71-81.

[84] Lemoine D., Cochard H., Granier A., Within crown variation in hydraulic architecture in beech (Fagus sylvatica L.): evidence for a stomatal control of xylem embolism, Ann. For. Sci. 59 (2002) $19-27$.

[85] Leuschner C., Corners H., Icke R., Harmann K., Effinger D., Schreiber L., Chemical composition of the periderm in relation to in situ water absorption rates of oak, beech and spruce fine roots, Ann. For. Sci. 60 (2003) 763-772.

[86] Leuschner C., Hertel D., Schmid I., Koch O., Muhs A., Holscher D., Stand fine root biomass and fine root morphology in oldgrowth beech forests as a function of precipitation and soil fertility, Plant Soil 258 (2004) 43-56.

[87] Levitt J., Responses of plants to environmental stresses. II. Water, radiation, salt, and other stresses, Academic Press, New York, 1980, $607 \mathrm{p}$.

[88] Lloret F., Siscart D., Dalmases C., Canopy recovery after drought dieback in holm-oak Mediterranean forests of Catalonia (NE Spain), Glob. Change Biol. 10 (2004) 2092-2099.

[89] Loustau D., Berbigier P., Granier A., Hadj Moussa E., Interception loss, throughtfall and stemflow in a maritime pine stand. I. Variability of throughfall and stemflow beneath the pine canopy, J. Hydrol. 138 (1992) 449-467.

[90] Loustau D., Berbigier P., Granier A., Interception loss, throughtfall and stemflow in a maritime pine stand. II. An application of Gash's analytical model of interception, J. Hydrol. 138 (1992) 469-485.

[91] Lovisolo C., Schubert A., Effects of water stress on vessel size and xylem hydraulic conductivity in Vitis vinifera L., J. Exp. Bot. 49 (1998) 693-700

[92] Lu P., Biron P., Granier A., Cochard H., Water relations of adult Norway Spruce (Picea abies (L.) Karst.) under soil drought in the Vosges mountain: Whole-tree hydraulic conductance, xylem embolism and water loss regulation, Ann. Sci. For. 53 (1996) 113121.

[93] Maherali H., DeLucia E.H., Influence of climate-driven shifts in biomass allocation on water transport and storage in ponderosa pine, Oecologia 129 (2001) 481-491.

[94] Maherali H., Pockman W.T., Jackson R.B., Adaptive variation in the vulnerability of woody plants to xylem cavitation, Ecology 85 (2004) 2184-2199. 
[95] Martinez-Vilalta J., Pinol J., Beven K., A hydraulic model to predict drought-induced mortality in woody plants: an application to climate change in the Mediterranean, Ecol. Model. 155 (2002) 127-147.

[96] Martre P., Morillon R., Barrieu F., North G.B., Nobel P.S. Chrispeels M.J., Plasma membrane aquaporins play a significant role during recovery from water deficit, Plant Physiol. 130 (2002) 2101-2110.

[97] Mayr S., Cochard H., A new method for vulnerability analysis of small xylem areas reveals that compression wood of Norway spruce has lower hydraulic safety than opposite wood, Plant Cell Environ. 26 (2003) 1365-1371.

[98] Mc Naughton K.G., Black T.A., Evapotranspiration from a forest: A micrometeorological study, Water Resour. Res. 9 (1973) 15791590.

[99] Mcjannet D.L., Vertessy R.A., Clifton C.A., Observations of evapotranspiration in a break of slope plantation susceptible to periodic drought stress, Tree Physiol. 20 (2000) 169-177.

[100] Meinzer F., Functional convergence in plant responses to the environment, Oecologia 134 (2003) 1-11.

[101] Mencuccini M., The ecological significance of long-distance water transport: short-term regulation, long-term acclimation and the hydraulic costs of stature across plant life forms, Plant Cell Environ. 26 (2003) 163-182.

[102] Monteith J.L., Principles of environmental physics, Edward Arnold, London, 1973.

[103] Mueller R.C., Scudder C.M., Porter M.E., Trotter III R.T., Gehring C.A., Whitham T.G., Differential tree mortality in response to severe drought: evidence for long-term vegetation shifts, J. Ecol. 93 (2005) 1085-1093.

[104] Nardini A., Salleo S., Andri S., Circadian regulation of leaf hydraulic conductance in sunflower (Helianthus annuиs L. cv Margot), Plant Cell Environ. 28 (2005) 750-759.

[105] Pauly H., Belrose V., Sécheresse et canicule de l'été 2003 observations en 2004 des conséquences sur les peuplements forestiers adultes. Résultats détaillés pour les essences feuillues, Département de la Santé des Forêts, Bilan de la santé des forêts en 2004 (2005) 1-8.

[106] Pedersen B.S., The mortality of Midwestern overstory oaks as a bioindicator of environmental stress, Ecol. Appl. 9 (1999) 10171027.

[107] Pedersen B.S., The role of stress in the mortality of Midwestern oaks as indicated by growth prior to death, Ecology 79 (1998) 79-93.

[108] Penuelas J., Filella I., Deuterium labelling of roots provides evidence of deep water access and hydraulic lift by Pinus nigra in a Mediterranean forest of NE Spain, Environ. Exp. Bot. 49 (2003) 201-208.

[109] Pockman W.T., Sperry J.S., Vulnerability to xylem cavitation and the distribution of Sonoran desert vegetation, Am. J. Bot. 87 (2000) 1287-1299.

[110] Poole D.K., Miller P.C., The distribution of plant water stress and vegetation characteristics in southern California chaparral, Am. Midlands Nat. 105 (1981) 32-43.

[111] Pottu A., Dobbertin M., Needle-retention and density patterns in Pinus sylvestris in the Rhone Valley of Switzerland: comparing results of the needle-trace method with visual defoliation assessments, Can. J. For. Res. 30 (2000) 1973-1982.

[112] Power S.A., Temporal trends in twig growth of Fagus sylvatica L. and their relationships with environmental factors, For. 67 (1994) 13-30.

[113] Rambal S., Ourcival J.M., Joffre R., Mouillot F., Nouvellon Y., Reinchstein M., Rocheteau A., Drought controls over conductance and assimilation of a Mediterranean evergreen ecosystem: scaling from leaf to canopy, Glob. Change Biol. 9 (2003) 1813-1824.
[114] Rambal S., Water balance and pattern of root water uptake by a Quercus coccifera L. evergreen scrub, Oecologia 62 (1984) 1825.

[115] Rebetez M., Mayer H., Dupont O., Schnindler D., Gartner K., Kropp J., Menzel A., Heat and drought 2003 in Europe: a climate synthesis, Ann. For. Sci. 63 (2006) 567-575.

[116] Reichstein M., Falge E., Baldocchi D., Papale D., Valentini R., Aubinet M., Berbigier P., Bernhofer C., Buchmann N., Gilmanov T., Granier A., Grünwald T., Havránková K., Janous D., Knohl A., Laurela T., Lohila A., Loustau D., Matteucci G., Meyers T., Miglietta F., Ourcival J.M., Rambal S., Rotenberg E., Sanz M., Seufert G., Vaccari F., Vesala T., Yakir D., On the separation of net ecosystem exchange into assimilation and ecosystem respiration: review and improved algorithm, Glob. Change Biol. (2006) (in press).

[117] Reichstein M., Tenhunen J.D., Roupsard O., Ourcival J.M., Rambal S., Miglietta F., Peressotti A., Pecchiari M., Tirone G., Valentini R., Severe drought effects on ecosystem $\mathrm{CO}_{2}$ and $\mathrm{H}_{2} \mathrm{O}$ fluxes at tree Mediterranean evergreen sites: revision of current hypotheses? Glob. Change Biol. 8 (2002) 999-1017.

[118] Renaud J.P., Nageleisen L.M., Results from the European Network For Damage Monitoring, Département de la santé des forêts, Bilan de la santé des forêts en 2004, 2005, 21 p.

[119] Rood S.B., Patiño S., Coombs K., Tyree M.T., Branch sacrifice: cavitation-associated drought adaptation of riparian cottonwoods, Trees, Struct. Funct. 14 (2000) 248-257.

[120] Rouault G., Candau J.N., Lietier F., Nageleisen L.M., Martin J.C., Warzee N., Effects of drought and heat on forest insect populations in relation to the 2003 drought in Western Europe, Ann. For. Sci. 63 (2006) 611-622.

[121] Rust S., Roloff A., Acclimation of crown structure to drought in Quercus robur L. - intra- and inter-annual variation of abscission and traits of shed twigs, Basic Appl. Ecol. 5 (2004) 283-291.

[122] Rust S., Roloff A., Reduced photosynthesis in old oak (Quercus robur): the impact of crown and hydraulic architecture, Tree Physiol. 22 (2002) 597-601.

[123] Rutter A.J., An analysis of evaporation from a stand of Scots pine, in: Sopper W.E., Lull H.W. (Eds.), Forest Hydrology, Pergamon press, Oxford, 1967.

[124] Salinger S., Increasing climate variability and change: reducing the vulnerability, Clim. Change 70 (2005) 1-3

[125] Salleo S., Logullo M.A., Depaoli D., Zippo M., Xylem recovery from cavitation-induced embolism in young plants of Laurus nobilis: A possible mechanism, New Phytol. 132 (1996) 47-56.

[126] Saxe H., Cannell M.G.R., Johnsen Ø., Ryan M.G., Vourlitis G., Tree and forest functioning in response to global warming, New Phytol. 149 (2001) 369-400.

[127] Schär C., Vidale P.L., Lüthi D., Frei C., Häberli C., Mark A., Liniger M.A., Appenzeller C., The role of increasing temperature variability in European summer heatwaves, Nature 427 (2004) 332-336.

[128] Schume H., Grabner M., Eckmullner O., The influence of an altered groundwater regime on vessel properties of hybrid poplar, Trees-Struct. Funct. 18 (2004) 184-194.

[129] Siefritz F., Tyree M.T., Lovisolo C., Schubert A., Kaldenhoff R. PIP1 plasma membrane aquaporins in tobacco: From cellular effects to function in plants, Plant Cell 14 (2002) 869-876.

[130] Siwecki R., Ufnalski K., Review of oak stand decline with special reference to the role of drought in Poland, Eur. J. For. Pathol. 28 (1998) 99-112.

[131] Solberg S., Summer drought: a driver for crown condition and mortality of Norway spruce in Norway, For. Pathol. (2004) 34, 93-104.

[132] Sperry J.S., Nichols K.L., Sullival J.E.M., Eastlack S.E., Xylem embolism in ring-porous, diffuse-porous, and coniferous trees of northern Utah and interior Alaska, Ecol. 75 (1994) 1736-1752. 
[133] Sperry J.S., Hydraulic constraints on plant gas exchange, Agric. For. Meteorol. 104 (2000) 13-23.

[134] Sperry J.S., Hacke U.G., Oren R., Comstock J.P., Water deficits and hydraulic limits to leaf water supply, Plant Cell Environ. 25 (2002) 251-263.

[135] Sperry J.S., Pockman W.T., Limitation of Transpiration by Hydraulic Conductance and Xylem Cavitation in Betula occidentalis, Plant Cell Environ. 16 (1993) 279-287.

[136] Sperry J.S., Tyree M.T., Mechanism of water stress-induced xylem embolism, Plant Physiol. 88 (1988) 581-587.

[137] Stout D.L., Sala A., Xylem vulnerability to cavitation in Pseudotsuga menziesii and Pinus ponderosa from contrasting habitats, Tree Physiol. 23 (2003) 43-50.

[138] Stratton L., Goldstein G., Meinzer F.C., Stem water storage capacity and efficiency of water transport: their functional significance in a Hawaiian dry forest, Plant Cell Environ. 23 (2000) 99-106.

[139] Stribley G.H., Ashmore M.R., Quantitative changes in growth pattern of young woodland beech (Fagus sylvatica L.) in relation to climate and ozone pollution over 10 years, For. Ecol. Manage. 157 (2002) 191-204.

[140] Suarez M.L., Ghermandi L., Kitzberger T., Factors predisposing episodic drought-induced tree mortality in Nothofagus-site, climatic sensitivity and growth trends, J. Ecol. 92 (2004) 954-966.

[141] Swaty R.L., Deckert R.J., Whitham T.G., Gehring C.A., Ectomycorrhizal abundance and community composition shifts with drought: predictions from tree rings, Ecology 85 (2004) 10721084.

[142] Thomas F.M., Blank R., Hartmann G., Abiotic and biotic factors and their interactions as causes of oak decline in Central Europe, For. Pathol. 32 (2002) 277-307.

[143] Tissier J., Lambs L., Peltier J.P., Marigo G., Relationships between hydraulic traits and habitat preference for six Acer species occurring in the French Alps, Ann. For. Sci. 61 (2004) 81-86.

[144] Tyree M., Cochard H., Cruiziat P., Sinclair B., Ameglio T., Drought-induced leaf shedding in walnut: evidence for vulnerability segmentation, Plant Cell Environ. 16 (1993) 879-882.
[145] Tyree M.T., Nardini A., Salleo S., Sack L., El Omari B., The dependence of leaf hydraulic conductance on irradiance during HPFM measurements: any role for stomatal response? J. Exp. Bot. 56 (2005) 737-744.

[146] Tyree M.T., A dynamic model for water flow in a single tree: evidence that models must account for hydraulic architecture, Tree Physiol. 4 (1988) 195-217.

[147] Tyree M.T., Ewers F.W., Tansley review No. 34. The hydraulic architecture of trees and other woody plants, New Phytol. 119 (1991) 345-360.

[148] Tyree M.T., Sperry J.S., Do woody plants operate near the point of catastrophic xylem dysfunction caused by dynamic water stress? Answers from a model, Plant Physiol. 88 (1988) 0574-0580.

[149] Tyree M.T., Zimmermann M.H., Xylem Structure and the Ascent of Sap, Springer, Berlin, 2002.

[150] Van Den Honert T.H., Water transport in plants as a catenary process, in: Interaction of water and porous materials, Discuss. Faraday Soc. 3 (1948) 146-153

[151] Wargo P.M., Armillaria mellea and Agrilus bilineatus and mortality of defoliated oak trees, For. Sci. 23 (1977) 485-492.

[152] Wargo P.M., Consequence of environmental stress on oak: Predisposition to pathogens, Ann. Sci. For. 53 (1996) 359-368.

[153] Webster R., Rigling A., Walthert L., An analysis of crown condition of Picea, Fagus and Abies in relation to environment in Switzerland, Forestry 69 (1996) 347-355.

[154] White J.W.C., Stable hydrogen isotope ratios in plants: a review of current theory and some potential applications, in: Rundel P.W., Ehleringer J.R., Nagy K.A. (Eds.), Stable Isotopes in Ecological Research, Ecological studies 68, Springer-Verlag, New York, 1989.

[155] Wyckoff P.H., Clark J.S., The Relationship between growth and mortality for seven co-occurring tree species in the southern Appalachian Mountains, J. Ecol. 90 (2002) 604-615.

[156] Zimmermann M.H., Hydraulic architecture of some diffuseporous trees, Can. J. Bot. 56 (1978) 2286-2295. 